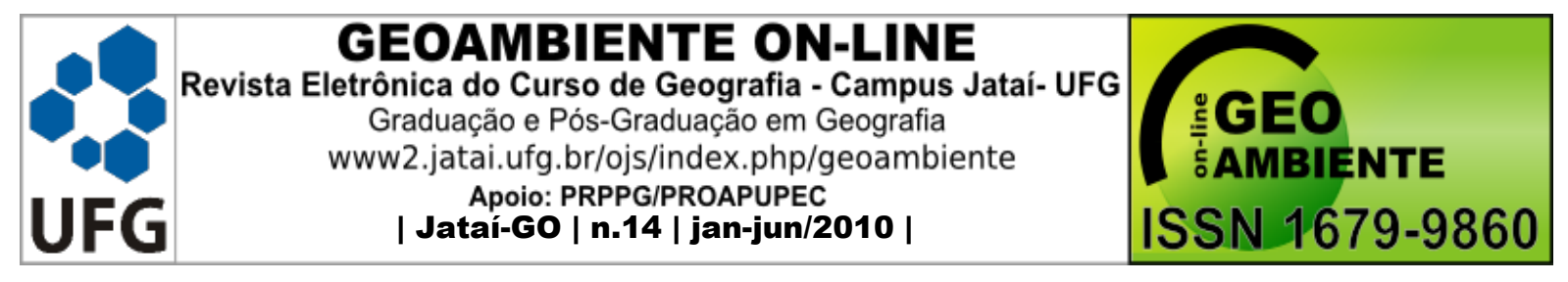

\title{
ANÁLISE DA FRAGILIDADE AMBIENTAL NO MUNICÍPIO DE TAMBOARA - PR: APLICAÇÃO E ESTUDO COMPARATIVO DE DUAS METODOLOGIAS
}

Rafael Marques dos Santos $^{1}$, Maria Teresa de Nóbrega ${ }^{2}$, Raniere Garcia Paiva ${ }^{3}$, Hélio Silveira ${ }^{4}$.

(1 - Universidade Estadual de Maringá - Graduando em Geografia/Bolsista Iniciação Científica - PIBIC/CNPq/FA-UEM, CEP 87020-030, Maringá- Paraná-Brasil, geografia.rafael@gmail.com, 2 - Professora Associado Nível A, mtnobrega@uol.com.br, -3 - Mestrando em Geografia - Bolsista Capes, ranieregpaiva@gmail.com, 4 - Professor doutor do dep. de Geografia, hesilveira70@hotmail.com).

\section{Resumo}

Os mapas de fragilidade e/ou vulnerabilidade ambiental são ferramentas que fornecem importantes subsídios para a gestão territorial e a elaboração do Zoneamento Ecológico Econômico (ZEE), visando mostrar, em termos de intensidade e de distribuição espacial, a susceptibilidade do meio físico, considerando-se os fatores geológicos, geomorfológicos e pedológicos, e as suas respostas às pressões antrópicas. O objetivo principal do trabalho é determinar e mapear a fragilidade ambiental na área do município de Tamboara - PR com a aplicação de duas metodologias, realizando um estudo comparativo entre elas. As duas metodologias adotadas têm por fundamento o conceito da Ecodinâmica que, a partir de uma abordagem sistêmica, propõe uma classificação fundamentada no estado de equilíbrio dinâmico do meio (estabilidade-instabilidade morfodinâmica). Os procedimentos operacionais envolvidos para a obtenção dos mapas de fragilidade incluem análises do relevo, solos, geologia, clima e uso do solo. A análise integrada possibilita a obtenção de produtos síntese que expressam diferentes graus de fragilidade do ambiente em função das suas características genéticas e das condições geradas pelas formas de uso e ocupação.

Palavras Chave: Fragilidade potencial. Fragilidade emergente, Ecodinâmica.

\section{Abstract}

Artigo recebido para publicação em 27 de Setembro de 2009;

Artigo aprovado para publicação em 06 de junho de 2010 


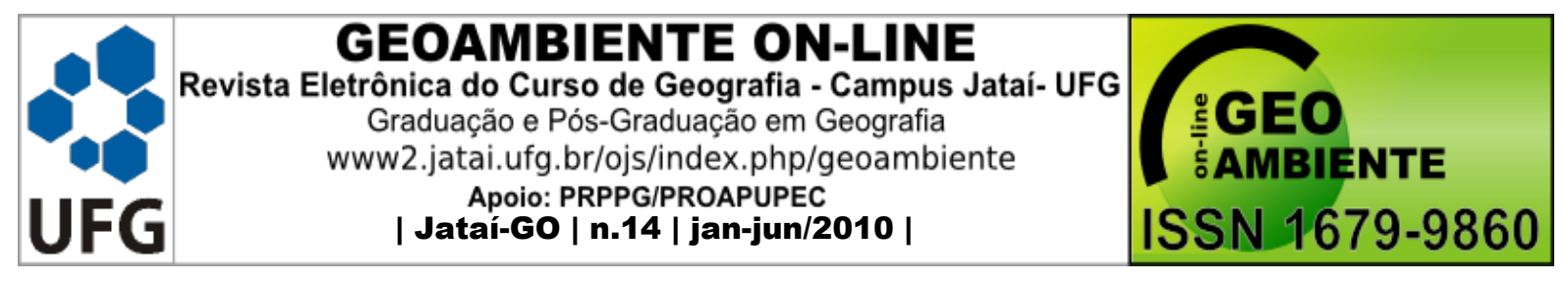

ANALYSIS OF THE MUNICIPALITY OF ENVIRONMENTAL FRAGILITY

TAMBOARA - BRAZIL: APPLICATION AND COMPARATIVE STUDY OF TWO

METHODOLOGIES

The maps of fragility and / or environmental vulnerability are tools that provide valuable information about land management and development of regional ecology - Economic Zone (EEZ), aiming to show in terms of intensity and spatial distribution, the susceptibility of the physical environment, considering the factors of geology, geomorphology and soil, and their responses to anthropogenic pressures. The main objective is to determine and map the environmentally fragile area of the municipality of Tamboara - PR with the use of two methodologies, conducting a comparative study between them. The two methodologies used are based on the concept of Ecodinâmica that, from a systemic approach, proposes a classification based on the steady state of the environment (stability-instability morphodynamics). Operating procedures involved to obtain the fragility maps include analysis of the relief, soils, geology, climate and land use. The integrated analysis enables the achievement of synthesis products that express different degrees of fragility of the environment according to their genetic characteristics and the conditions generated by the forms of use and occupation.

Keywords: Potential fragility. Fragile emerging. Ecodinâmica.

\section{Résumé}

\section{ANALYSE DE LA MUNICIPALITÉ DE TAMBOARA - BRAZIL FRAGILITÉ DE L'ENVIRONNEMENT - PR: APPLICATION ET ÉTUDE COMPARATIVE DE DEUX MÉTHODES}

Les cartes de fragilité et / ou la vulnérabilité de l'environnement sont des outils qui constituent une contribution importante pour l'élaboration de la gestion territoriale et écologique économique de zonage (ZEE), visant à montrer en termes d'intensité et la répartition spatiale, la sensibilité de l'environnement physique, compte tenu Les facteurs de la géologie, la géomorphologie et les sols, et leurs réponses aux pressions anthropiques. L'objectif principal est de déterminer et de cartographier les zones écologiquement fragiles de la municipalité de Tamboara - PR à l'utilisation des deux méthodes, une étude comparative entre eux. Les deux méthodes utilisées sont basées sur le concept de Ecodinâmica que, à partir d'une approche systémique, propose une classification fondée sur l'état d'équilibre de l'environnement 


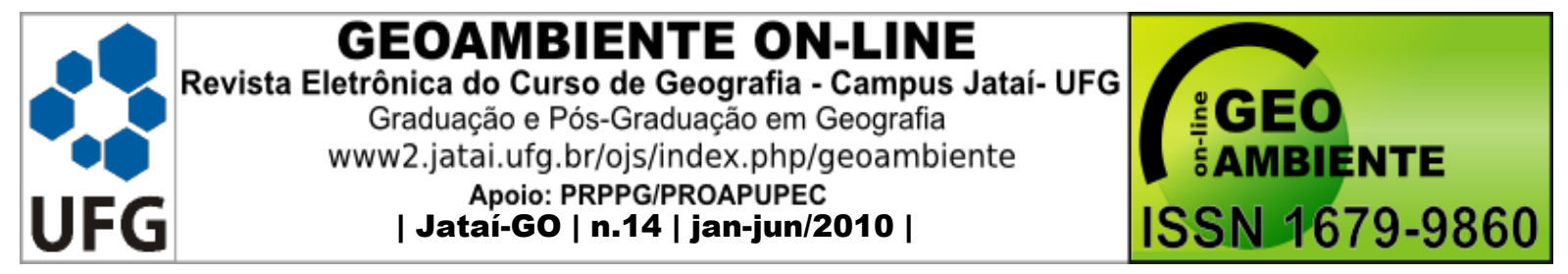

(morphodynamique stabilité-instabilité). Les procédures d'exploitation concerné pour obtenir les cartes fragilité comprennent l'analyse du relief, les sols, la géologie, le climat et l'utilisation des terres. L'analyse intégrée permet la réalisation de produits de synthèse qui expriment différents degrés de fragilité de l'environnement en fonction de leurs caractéristiques génétiques et les conditions générées par les formes d'utilisation et d'occupation.

Mosts - clés: Fragilité potentielle. Fragile émergents. écodynamique.

\section{Introdução}

A paisagem rural é construída, ao longo do tempo, pelas relações de apropriação e manejo dos recursos naturais. Entretanto, a inadequação de sistemas de produção em determinadas áreas gera impactos, degradação ambiental e social do espaço rural.

Os sistemas de produção agrícola provocam transformações, em maior ou menor grau, nos elementos que constituem a estrutura geoecológica da paisagem rural, e, qualquer interferência em um dos seus componentes (relevo, solos, vegetação, clima e recursos hídricos) se reflete sobre os outros elementos, alterando o seu equilíbrio dinâmico. Quando este equilíbrio é alterado, segundo Ross (1990), estados de desequilíbrios temporários ou permanentes são gerados, modificando o funcionamento do sistema natural e, muitas vezes, desencadeando processos de degradação.

Além do ambiente natural, como enfatiza Spörl (2001), o meio antrópico é parte fundamental no entendimento do processo sendo, portanto, imprescindível se levar em conta, de um lado, as potencialidades dos recursos naturais, as fragilidades dos ambientes, e por outro lado, os anseios e as necessidades da sociedade.

Os estudos relativos à fragilidade dos ambientes são de extrema importância ao Planejamento Ambiental, onde a identificação dos ambientes naturais e suas fragilidades potenciais e emergentes proporcionam uma melhor definição das diretrizes e ações a serem implementadas no espaço físico-territorial, servindo de base para o zoneamento e fornecendo subsídios à gestão do território (SPÖRL, 2001).

A paisagem rural, nesta pesquisa, é percebida como um sistema - o agroecossistema com uma estrutura e funcionamento, onde a definição das suas fragilidades e potencialidades contribui para a proposta de modelos agrícolas sustentáveis. 


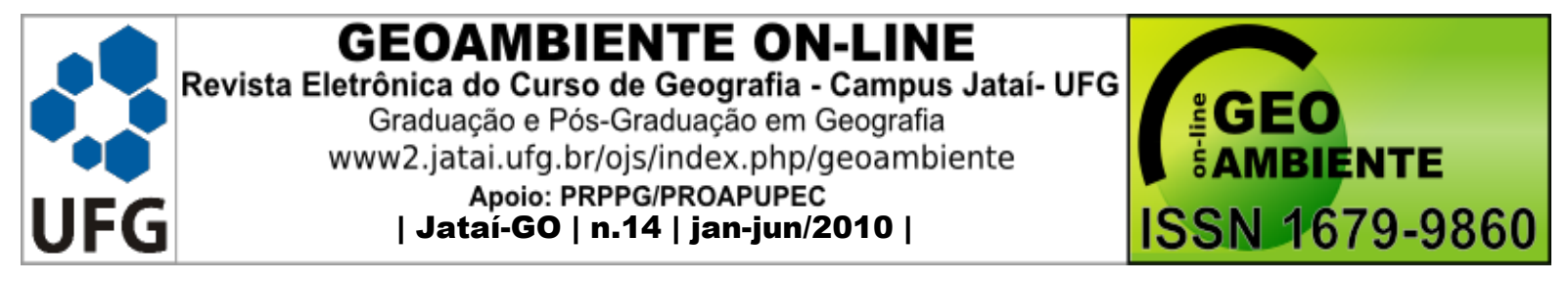

A fragilidade potencial compreende a integração dos elementos físicos naturais, como a geomorfologia, tipos de solo, declividade, geologia, entre outros, enquanto a fragilidade emergente compreende a análise integrada da fragilidade potencial do meio natural com o tipo de uso do solo.

Ross (1992), abordando o registro cartográfico e a questão taxonômica do relevo, salienta que as formas dos terrenos, de diferentes proporções, possuem uma explicação genética e são interdependentes e interrelacionadas aos demais componentes da natureza (geologia, cobertura pedológica, clima, hidrografia e vegetação).

Partindo dessas concepções e com o interesse de utilizá-las nos estudos de planejamento ambiental, Ross (op. cit.) ampliou o uso e o conceito, estabelecendo as unidades ecodinâmicas instáveis ou de instabilidade emergente em vários graus, desde instabilidade muito fraca até muito forte, aplicando o mesmo critério para as unidades ecodinâmicas estáveis. Para a construção da carta de fragilidade ambiental potencial e emergente, este autor utiliza produtos intermediários (carta pedológica, de uso de solo, geomorfológica e de cobertura vegetal, segundo o seu grau de proteção).

A análise empírica da fragilidade ambiental proposta por Ross (1994) fundamenta-se no conceito das Unidades Ecodinâmicas preconizado por Tricart (1977), que parte do pressuposto que na natureza a troca de energia e matéria se relaciona em um equilíbrio dinâmico. De acordo com este conceito, Tricart (op cit) considera que os ambientes são estáveis quando estão em equilíbrio dinâmico e foram poupados da ação humana, encontrando-se em estado natural. Entretanto, quando este equilíbrio sofre as intervenções antrópicas, passa a ser considerado como uma unidade instável.

Os mapas de fragilidade e/ou vulnerabilidade ambiental são ferramentas que atendem a essa necessidade. São instrumentos de avaliação das fragilidades e potencialidades que sintetizam as características naturais dos meios e as restrições e/ou aptidões em face de distintas formas de uso e ocupação. A elaboração de mapas de fragilidade ambiental mostra, assim, em termos de intensidade e de distribuição espacial, a susceptibilidade do meio físico, considerando-se os fatores geológicos, geomorfológicos e pedológicos, e as suas respostas às pressões antrópicas.

Os mapeamentos de fragilidade ambiental possibilitam a indicação de áreas onde os graus de fragilidade são mais baixos, com maiores opções de uso e ocupação; e aquelas de graus de fragilidade mais altos, áreas mais vulneráveis, onde as opções de uso são mais 


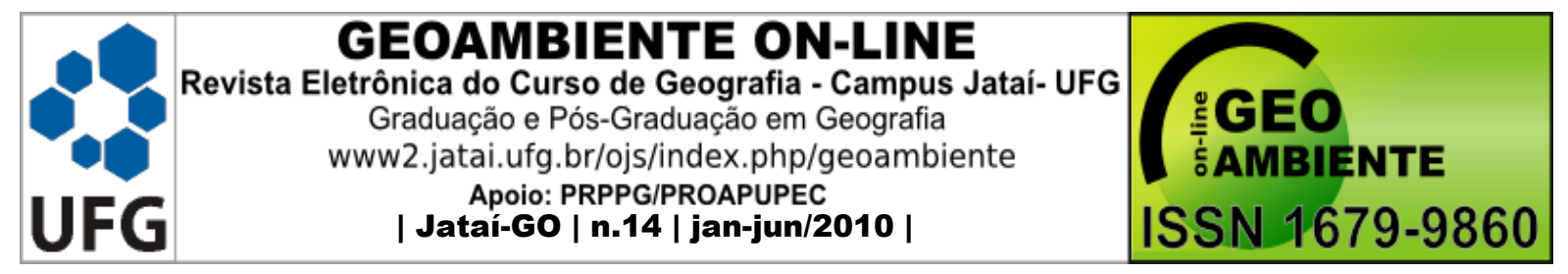

reduzidas, exigindo-se, ainda, a aplicação de técnicas mais adequadas. Fornecem deste modo, importantes subsídios para a gestão territorial e o Zoneamento Ecológico-Econômico (ZEE).

O mapa de fragilidade ambiental constitui um dos principais instrumentos empregados pelos órgãos públicos na elaboração do planejamento territorial ambiental. O mapeamento da fragilidade ambiental permite avaliar as potencialidades do meio ambiente combinando suas características naturais com suas restrições. O mapeamento das fragilidades agrupa os ambientes em relação aos diferentes níveis de fragilidade. Tais informações permitem ao planejador elaborar ações de intervenção técnica, adequadas a cada condição (KAWAKUBO, 2005).

Neste contexto, este trabalho realizou o mapeamento de fragilidade ambiental na área do município de Tamboara, Estado do Paraná, com a aplicação de duas metodologias propostas por Ross (1994). Uma das metodologias resulta na fragilidade ambiental por meio da dissecação do relevo, e a outra na fragilidade ambiental com base nas classes de declividades.

\section{Materiais e Métodos}

O município de Tamboara (Figura 1) se localiza na região Noroeste do estado do Paraná, entre as latitudes de $23^{\circ} 07^{\prime} 49^{\prime \prime} \mathrm{S}$ e $23^{\circ} 16^{\prime} 02^{\prime \prime} \mathrm{S}$, e entre as longitudes de $52^{\circ} 25^{\prime} 14^{\prime \prime}$ W e $52^{\circ} 32^{\prime} 47^{\prime}$ 'W, com uma área de $194,735 \mathrm{~km}^{2}$, em zona de contato arenito/basalto.

O arenito da Formação Caiuá domina os topos dos interflúvios mais elevados verificado na elaboração da hipsometria da área, enquanto que o basalto da Formação Serra Geral aflora no fundo dos vales e ao longo de vertentes das colinas mais baixas.

O clima da área é o Cfa da classificação de Köeppen (1948), com temperatura variando entre $22^{\circ} \mathrm{C}$ e $18^{\circ} \mathrm{C}$. Corresponde ao tipo subtropical úmido mesotérmico, caracterizado por verões quentes, geadas pouco freqüentes, e com tendência de concentração das chuvas nos meses de verão, sem estação seca definida. As médias pluviométricas na área estão compreendidas entre 1300 e $1400 \mathrm{~mm}$.

A vegetação original era constituída pela Floresta Estacional Semidecidual Submontana (IBGE, 1993), tendo sido fortemente devastada dando lugar, inicialmente à cultura do café que foi, por sua vez, substituída pelas pastagens, principalmente, e por culturas de mandioca e, mais recentemente, ocorreu a introdução de soja/milho e a cana- de - açúcar no 


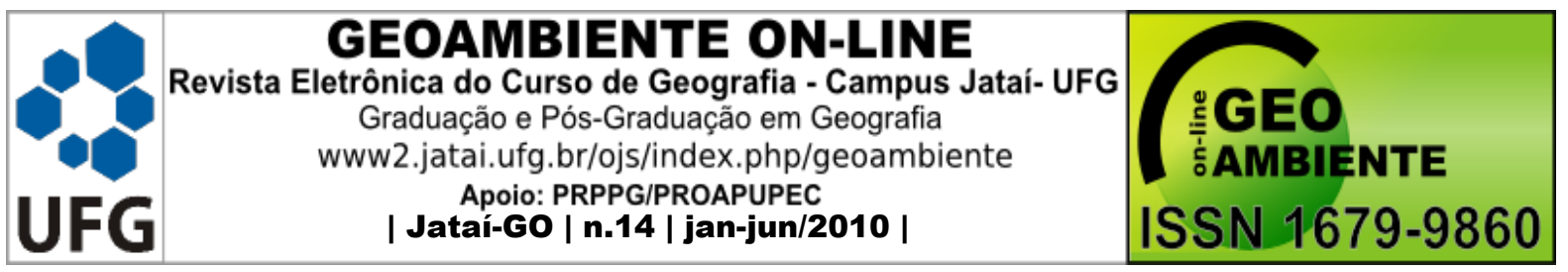

processo de uso do solo. Atualmente, a floresta aparece como pequenas manchas (capões) esparsos na área e, eventualmente ao longo dos cursos d'água.

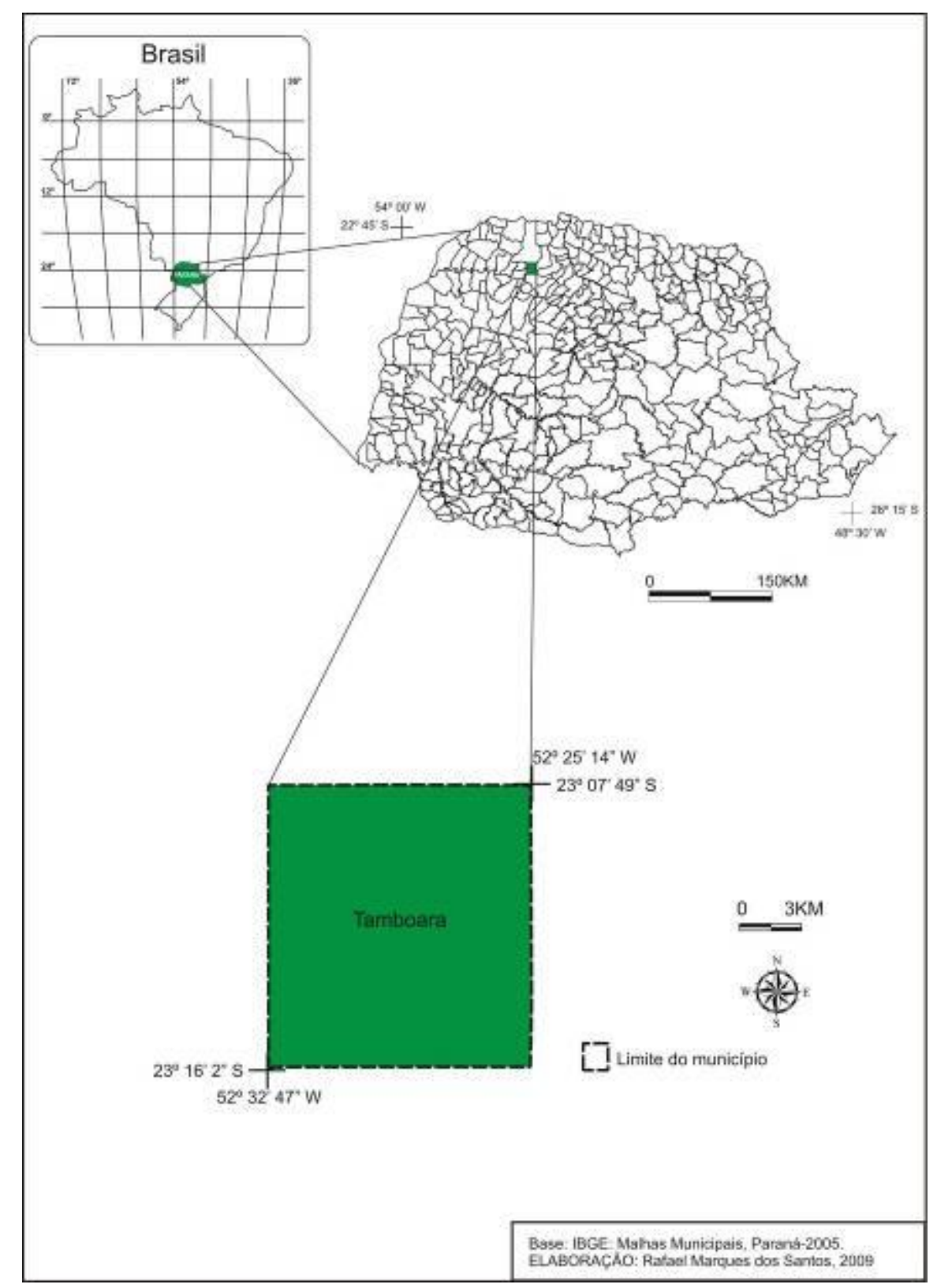

Figura 1. Localização do município de Tamboara - Paraná.

O relevo da região é caracterizado pela presença de colinas amplas com vertentes convexas e de declividades fracas a moderadas. Sobre esse relevo ocorrem os Latossolos Vermelhos, com texturas média ou argilosa, dependendo do substrato, nas posições de topo e 


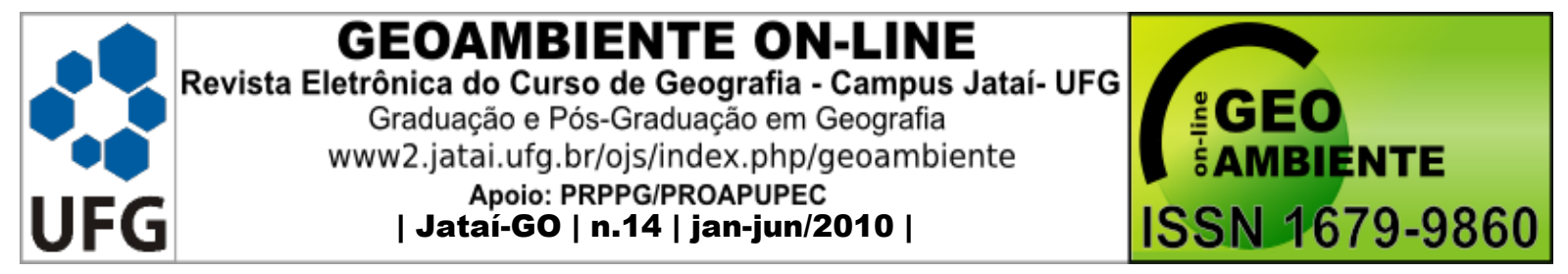

altas vertentes, e nas médias e baixas vertentes aparecem os Argissolos Vermelhos-amarelos, típicos ou abrúpticos.

O mapeamento da fragilidade ambiental foi realizado de acordo com as propostas metodológicas de Ross (1994):

- Fragilidade Ambiental por meio da dissecação do relevo: esta metodologia leva em conta a relação entre a dimensão interfluvial média e o entalhamento médio dos vales, correlacionando a primeira entre muito pequena a muito grande, com a segunda, de muito fraco à muito forte, tendo índices que vão de 11 a 55.

- Fragilidade Ambiental por meio da carta de declividade: neste procedimento, a variável relevo é baseada na carta clinográfica, sendo esta dividida em 5 classes, que atribuem peso de muito fraca à muito forte.

Segundo Ross (op. Cit), a análise empírica da fragilidade exige estudos básicos do relevo, da litologia-estrutura, do solo, do uso do solo e do clima, o que implica em levantamento de dados em campo e na geração de cartas temáticas de geomorfologia (padrão de formas de relevo), geologia, clinográfica (Figura 02), solos (Figura 03) e uso do solo (Figura 04). 


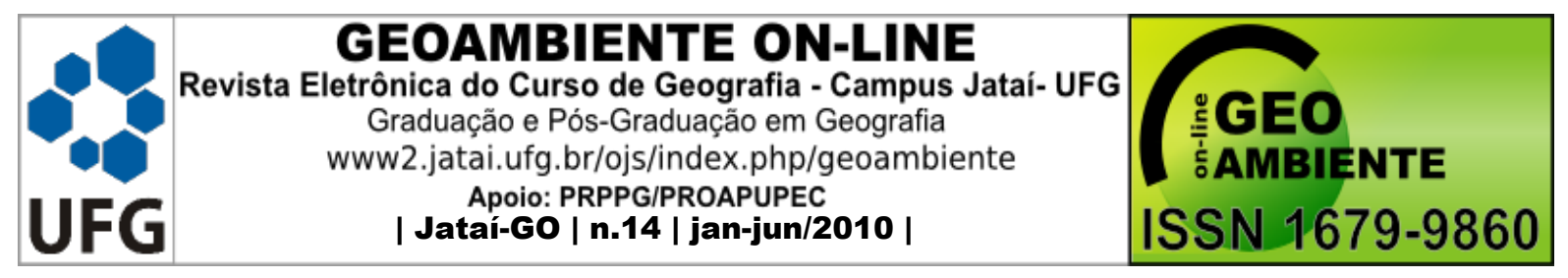

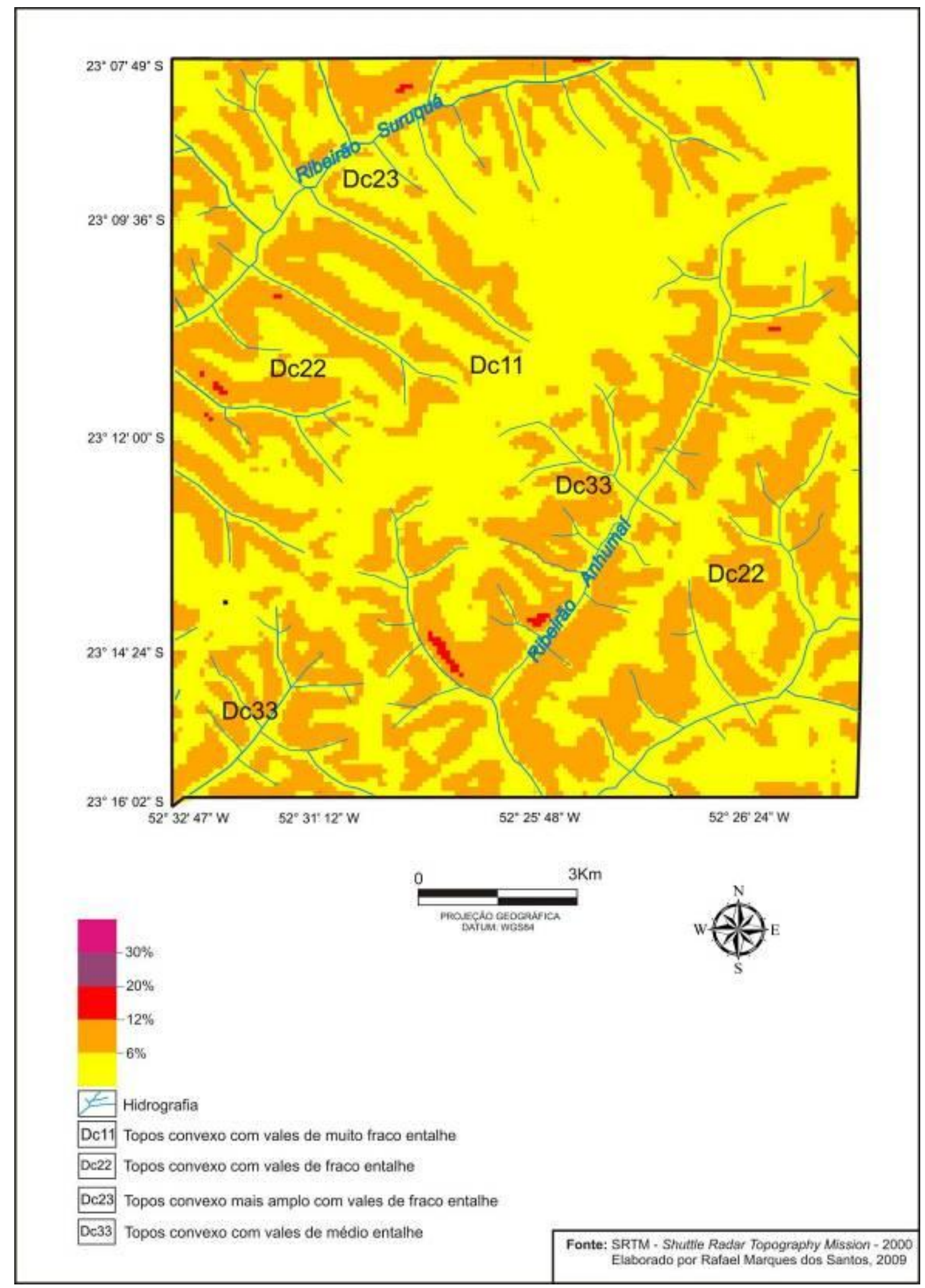

Figura 2. Declividade e padrões de formas de relevo (Dc) do município de Tamboara - Paraná. 


\begin{tabular}{|c|c|c|}
\hline & $\begin{array}{c}\text { GEOAMBIENTE ON-LINE } \\
\text { Revista Eletrônica do Curso de Geografia - Campus Jatai- UFG } \\
\text { Graduacăo e Pós-Graduacăo em Geografia } \\
\text { www2.jataia.ufg. br/ojs/index. php/geoeambiente } \\
\text { Apoio: PRPPG/PROAPUPEC } \\
\text { | Jatai-Go | n.14 | jan-jun/2010 | }\end{array}$ & ISSI \\
\hline
\end{tabular}

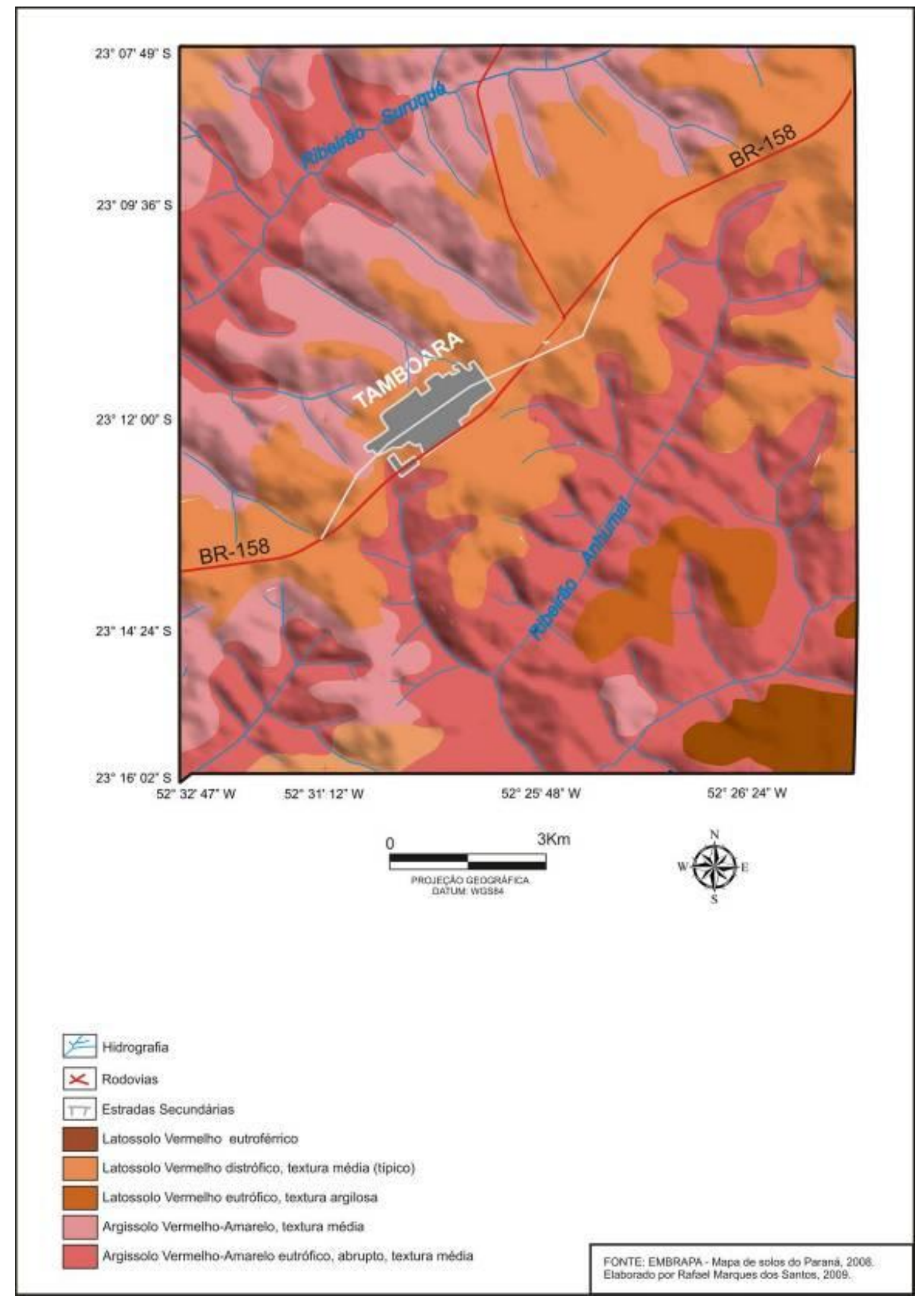

Figura 3. Solos do município de Tamboara - Paraná. 


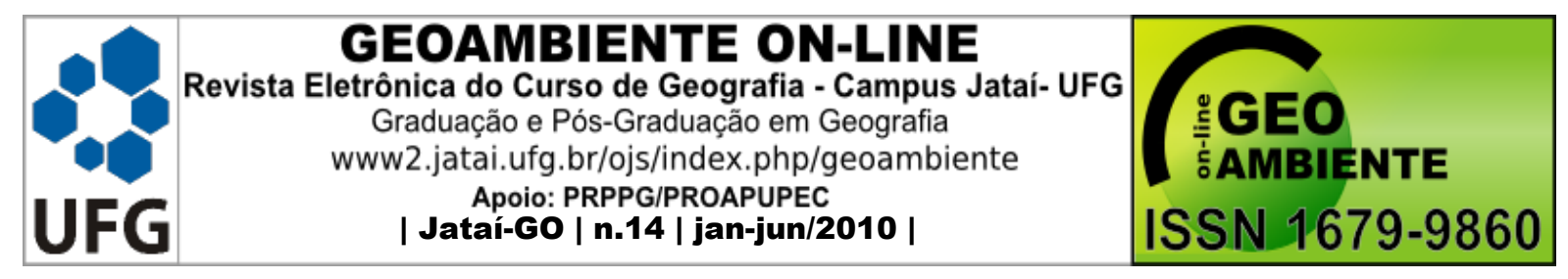

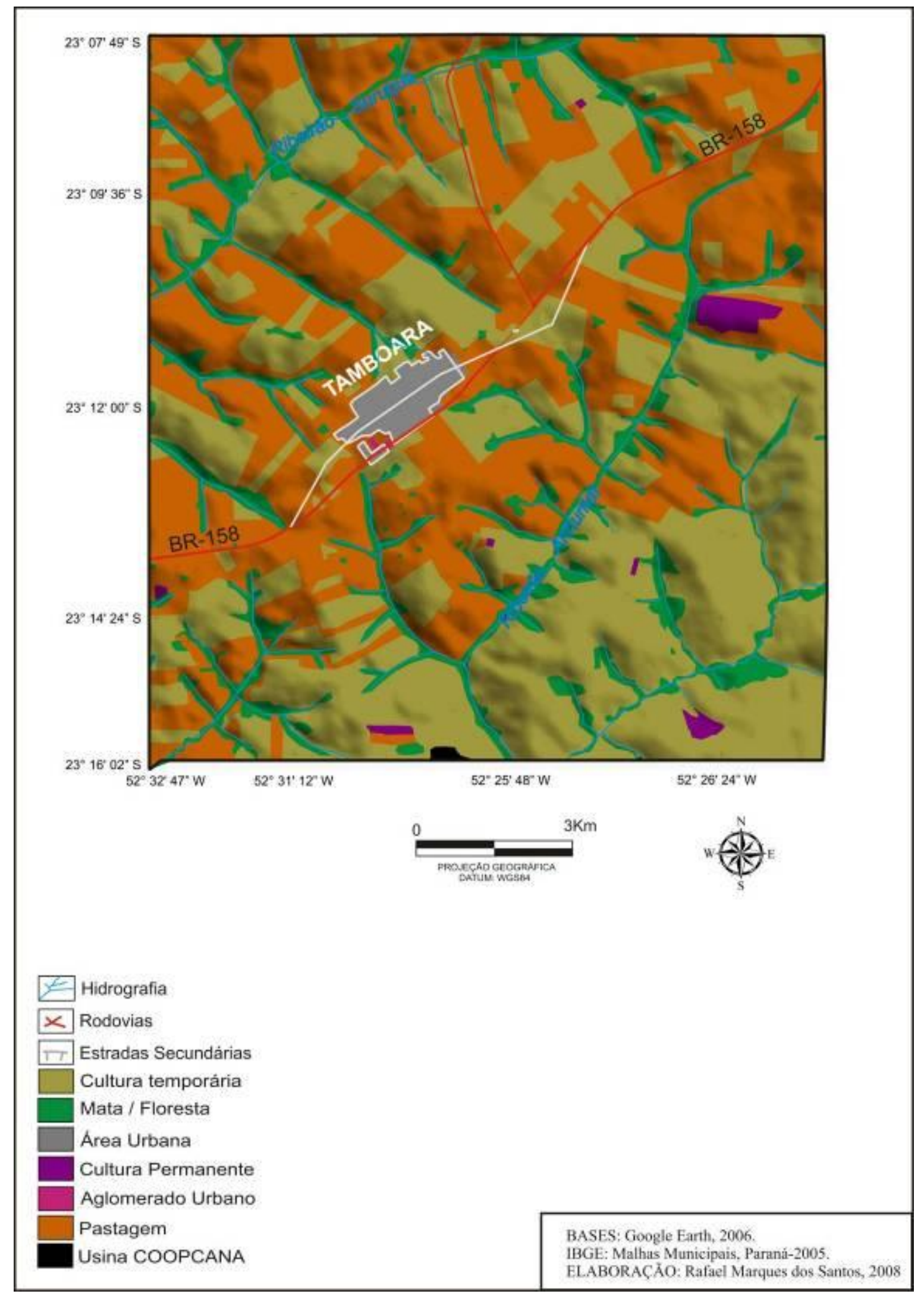

Figura 4. Uso do Solo do município de Tamboara - Paraná. 


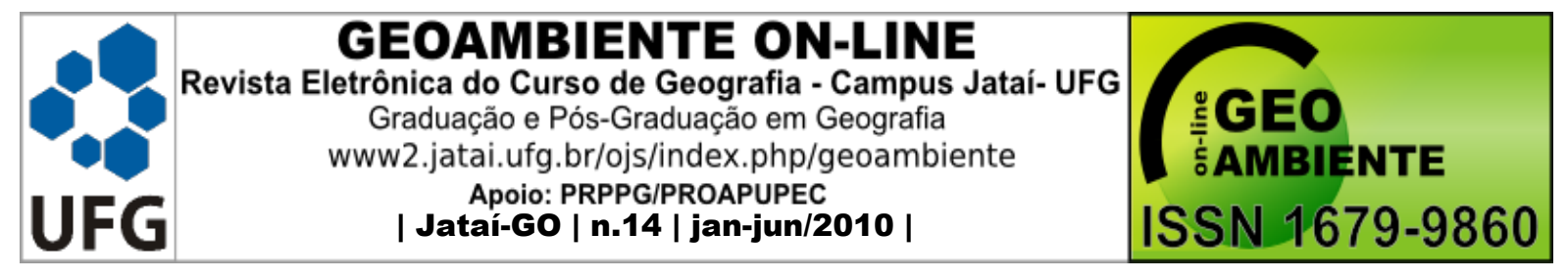

Em cada carta temática o elemento representado (padrão de relevo, declividade, solos, vegetação e uso do solo) é classificado, segundo critérios propostos pelo autor, com atribuição de um índice (atributo) para cada classe. Os graus de fragilidade são indicados, desta forma, por um número onde o primeiro dígito se refere à classe de declividade e/ou ao padrão de formas do relevo (de acordo com a escala adotada) e o seu grau de fragilidade; o segundo indica o grau de fragilidade do solo, e o terceiro o grau de fragilidade em função da cobertura vegetal e do uso. A variável cobertura vegetal/uso do solo indica as áreas onde o equilíbrio dinâmico foi rompido, provocando situações de risco e as áreas onde a estabilidade permanece (SPÖRL, 2001).

A definição dos graus de fragilidade ambiental é obtida a partir do cruzamento das cartas temáticas, na seguinte ordem:

- carta de declividades e/ou de padrão de formas de relevo x carta de solos, define os graus de fragilidade potencial (carta de fragilidade potencial - vulnerabilidade natural);

- carta de fragilidade potencial x carta de uso do solo, define os graus de fragilidade emergente (carta de fragilidade emergente - vulnerabilidade associada aos graus de proteção que os diferentes tipos de uso e cobertura vegetal exercem).

Fragilidade emergente, além de considerar os elementos naturais, já constantes na fragilidade potencial, acrescenta-se o elemento humano, ou seja, uso e ocupação da terra, que se caracteriza pela maneira como o ser humano utiliza o solo..

Ross (1994) sistematizou uma hierarquia nominal de fragilidade representadas por códigos: muito fraca (1), fraca (2), média (3), forte (4) e muito forte (5). Estas categorias expressam especialmente a fragilidade do ambiente.

A carta de padrão de formas de relevo foi elaborada utilizando-se a matriz dos índices de dissecação do relevo (Tabela 1), apresentada por Ross (1992), baseada na relação da densidade de drenagem/distância interfluvial média para a dissecação no plano horizontal e nos graus de entalhamento dos canais de drenagem para a dissecação no plano vertical (KAWAKUBO et al., 2005). As medidas de dimensão interfluvial e/ou de densidade de drenagem foram realizadas sobre imagens SRTM (Shuttle Radar Topographic Mission, 2000) e do satélite Landsat 7 ETM + da área de estudo obtidas através do site: www.glcf.edu.gov, adotando-se a matriz dos índices de dissecação do relevo apresentada na Tabela 1. 


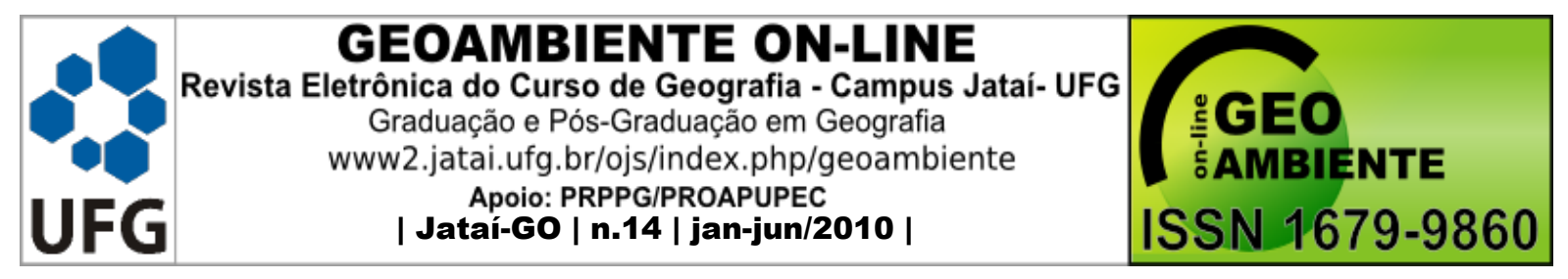

Tabela 1 - Matriz dos Índices de Dissecação do Relevo

\begin{tabular}{|c|c|c|c|c|c|}
\hline $\begin{array}{c}\text { DIMENSÃO } \\
\text { INTERFLUVIAL } \\
\text { MÉDIA (CLASSES) }\end{array}$ & $\begin{array}{c}\text { MUITO } \\
\text { GRANDE } \\
\text { (1) }\end{array}$ & $\begin{array}{c}\text { GRANDE } \\
\text { (2) }\end{array}$ & $\begin{array}{c}\text { MÉDIA } \\
\text { (3) }\end{array}$ & $\begin{array}{c}\text { PEQUENA } \\
\text { (4) }\end{array}$ & $\begin{array}{c}\text { MUITO } \\
\text { PEQUENA } \\
(5)\end{array}$ \\
\hline $\begin{array}{l}\text { ENTALHAMENTO MÉDIO } \\
\text { DOS VALES (CLASSES) }\end{array}$ & $>3750 \mathrm{~m}$ & $\begin{array}{l}\text { 1750m a } \\
\text { 3750m }\end{array}$ & $\begin{array}{l}750 \mathrm{~m} \text { a } \\
1750 \mathrm{~m}\end{array}$ & $\begin{array}{l}250 \mathrm{~m} \text { a } \\
750 \mathrm{~m}\end{array}$ & $<250 \mathrm{~m}$ \\
\hline $\begin{array}{c}\text { MUITO FRACO (1) } \\
<20 \mathrm{~m}\end{array}$ & 11 & 12 & 13 & 14 & 15 \\
\hline $\begin{array}{l}\text { FRACO (2) } \\
20 \text { a } 40 \mathrm{~m}\end{array}$ & 21 & 22 & 23 & 24 & 25 \\
\hline $\begin{array}{l}\text { MÉDIO (3) } \\
40 \text { a } 80 \mathrm{~m}\end{array}$ & 31 & 32 & 33 & 34 & 35 \\
\hline $\begin{array}{l}\text { FORTE (4) } \\
80 \text { a } 160 \mathrm{~m}\end{array}$ & 41 & 42 & 43 & 44 & 45 \\
\hline $\begin{array}{c}\text { MUITO FORTE (5) } \\
>160 \mathrm{~m}\end{array}$ & 51 & 52 & 53 & 54 & 55 \\
\hline
\end{tabular}

Fonte: ROSS, 1996 - Padrões de dissecação do relevo aplicável para escalas médias

$\mathrm{Na}$ carta clinográfica foram adotadas as classes de declividade com os intervalos definidos e graus de fragilidade (Tabela 2) atribuídos por (ROSS, 1994 e 1996).

Tabela 2 - Graus de Fragilidade em decorrência da Declividade

\begin{tabular}{ccc}
\hline Atributo & Classes de Fragilidade & Percentual \\
\hline 1 & Muito Fraca & até $6 \%$ \\
2 & Fraca & de $6 \%$ a $12 \%$ \\
3 & Média & de $12 \%$ a $20 \%$ \\
4 & Forte & de $20 \%$ a $30 \%$ \\
5 & Muito Forte & acima de $30 \%$ \\
\hline
\end{tabular}

Segundo o autor ( op cit), para a determinação dos limites das classes de declividade foram considerados aqueles empregados nos estudos de capacidade uso/aptidão agrícola, associados com valores limites críticos conhecidos em geotecnia, indicativos do vigor dos processos erosivos e dos riscos de escorregamentos/ deslizamentos e inundações freqüentes.

Para a variável solo, o mesmo autor, com base nas características de textura, estrutura, plasticidade, grau de coesão das partículas e profundidade/espessura dos horizontes 


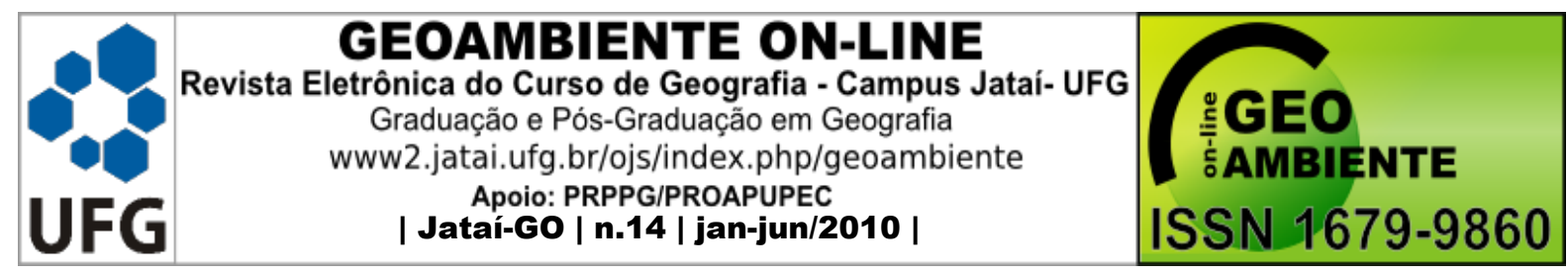

superficiais e subsuperficias e, ainda, em resultados de diversas pesquisas e em dados obtidos em campo, propõe classes de fragilidade ou de erodibilidade dos solos, considerando o escoamento superficial difuso e concentrado das águas pluviais (ROSS, 1996). Na Tabela 3 são indicados os graus de fragilidade para os tipos de solos que ocorrem na área de estudo e que serão adotados no desenvolvimento do projeto, com base nos atributos originalmente elencados por Ross (op cit.).

Tabela 3 -Graus de Fragilidade em decorrência do tipo de solo.

\begin{tabular}{|c|c|c|}
\hline Atributo & $\begin{array}{c}\text { Classe de tipo de } \\
\text { solo }\end{array}$ & Tipo de solo \\
\hline 1 & Muito baixa & $\begin{array}{l}\text { Latossolo Vermelho Eutroférrico textura argilosa } \\
\text { Latossolo Vermelho Eutrófico textura argilosa }\end{array}$ \\
\hline $\begin{array}{l}2 \\
3\end{array}$ & $\begin{array}{l}\text { Baixo } \\
\text { Médio }\end{array}$ & $\begin{array}{l}\text { Latossolo Vermelho Distrófico textura média (Típico) } \\
\text { Nitossolo Vermelho }\end{array}$ \\
\hline 4 & Forte & $\begin{array}{l}\text { Argissolo Vermelho amarelo textura média/argilosa, } \\
\text { Argissolo Vermelho-amarelo textura média e/ou abruptico, } \\
\text { Argissolo Vermelho amarelo textura média, }\end{array}$ \\
\hline 5 & Muito Forte & $\begin{array}{l}\text { Cambissolos, Neossolos Litólicos, Neossolos Quartzarênicos, } \\
\text { Gleissolos }\end{array}$ \\
\hline
\end{tabular}

A carta de vegetação/uso do solo possibilita a análise da proteção dos solos pela cobertura vegetal. Os graus de proteção dos solos conferidos pela cobertura natural ou cultivada propostos por Ross (1994) estão relacionados na Tabela 4.

Tabela 4 - Graus de Proteção por tipos de Cobertura Vegetal

\begin{tabular}{ccl}
\hline Atributo & $\begin{array}{l}\text { Graus de } \\
\text { Proteção }\end{array}$ & Tipo de cobertura Vegetal \\
\hline 1 & $\begin{array}{c}\text { Muito Alta } \\
\text { Alta }\end{array}$ & $\begin{array}{l}\text { Mata natural e florestas cultivadas com biodiversidade. } \\
\text { Formações arbustivas naturais com estrato herbáceo denso. Formações } \\
\text { arbustivas (mata secundária). Mata homogênea de Pinus densa. Pastagens } \\
\text { cultivadas sem pisoteio. } \\
\text { Cultivo de ciclo longo com práticas conservacionistas (café, laranja). } \\
\text { Silvicultura de eucaliptos com sub-bosques de nativas. Pastagens com } \\
\text { baixo pisoteio. } \\
\text { Cultura de ciclo longo de baixa densidade (café, laranja) com solo exposto } \\
\text { entre ruas, culturas de ciclo curto (milho, soja, algodão, mandioca, cana-de- } \\
\text { açúcar) com práticas conservacionistas. } \\
\text { Áreas desmatadas e queimadas recentemente, solo exposto por arado e } \\
\text { gradeação, solo exposto ao longo de caminhos e estradas, terraplanagens. } \\
\text { Cultura de ciclo curto sem práticas conservacionistas. }\end{array}$ \\
\hline 5 & Baixa \\
\hline
\end{tabular}




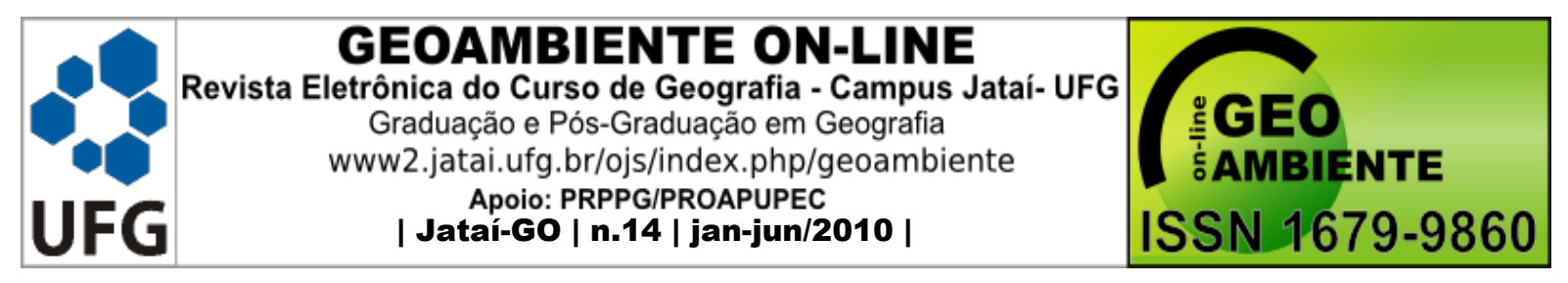

Para as cartas de fragilidade potencial e emergente proposta nas duas metodologias, foi adaptada a metodologia de Ross (1994), sendo classificada de forma hierárquica por números. O primeiro número representa o grau de fragilidade ou dissecação do relevo, o segundo número ou grau de fragilidade dos solos e o terceiro número encontrado apenas na fragilidade emergente se refere ao grau de fragilidade do uso do solo, tendo combinações diferentes conforme o grau de fragilidade encontrado no cruzamento dos elementos.

A base cartográfica foi elaborada com o auxilio de uma ferramenta geográfica, ou seja, o SIG, como o Global Mapper®, Envi®, Erdas®, ArcGis® e para finalização das cartas o software Corel Draw®. Sendo utilizada como base os dado SRTM (Suttle Radar Topografic Mission, disponibilizados gratuitamente pela NASA(National Aeronautics and Space Administration).

\section{3 - Resultados e Discussões}

3.1 Metodologia 1 - Mapas de Fragilidade Potencial e Fragilidade Emergente com apoio nas classes de declividade

A carta de fragilidade potencial de Tamboara (Figura 05) evidencia que os topos dos interflúvios, sobretudo aquele entre o ribeirão Suruquá e o ribeirão Anhumai, apresentam declividades inferiores a 6\%, o que corresponde, segundo o método adotado, a uma fragilidade muito fraca. Nessas áreas ocorrem os Latossolos Vermelhos, mas que apresentam texturas variadas em virtude da zona de contato arenito/basalto. Assim, a fragilidade é classificada como muito baixa quando nessas áreas ocorrem o Latossolo Vermelho férrico ou o Latossolo Vermelho de textura mais argilosa, enquanto que a presença de Latossolos Vermelhos de textura média implica em um aumento da fragilidade, que passa a ser considerada como média. A maior parte dos topos exibe, considerando-se declividade x solos, uma fragilidade média, com exceção dos topos situados na porção sudeste, no compartimento designado como Vale do Anhumai, onde ocorre o basalto e os solos apresentam textura mais argilosa. Aí ela se matem como muito baixa e baixa.

Ao longo das vertentes, desde a alta até a baixa vertente, as declividades variam entre $6 \%$ e $12 \%$, o que confere uma fragilidade fraca. Entretanto, estão recobertas pelos Argissolos que, por suas características pedológicas, se apresentam mais vulneráveis aos processos erosivos do que os Latossolos. Essa vulnerabilidade é, como no caso dos primeiros, acentuada pela textura. Desse modo, apesar da fragilidade fraca resultante da declividade, os solos 


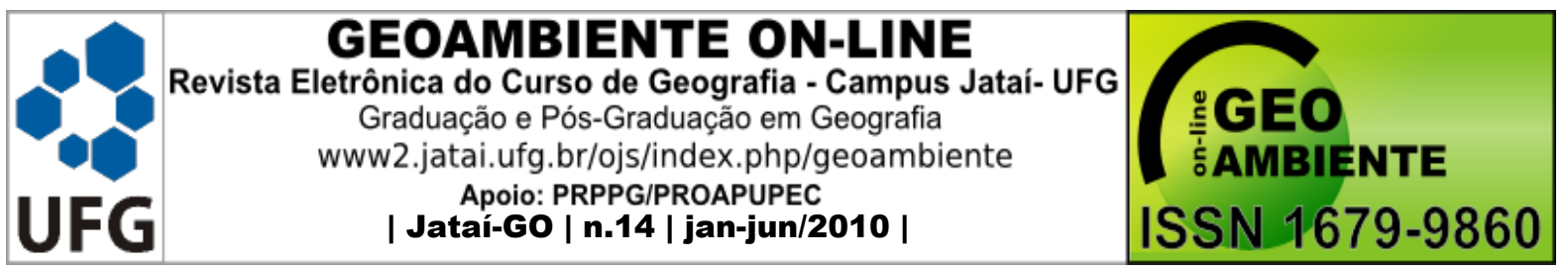

conferem à maior parte dessas vertentes, uma fragilidade forte, quando apresentam textura média (mais arenosa) e moderada quando exibem textura mais argilosa (vertentes do compartimento Vale do Anhumai, sobre o basalto).

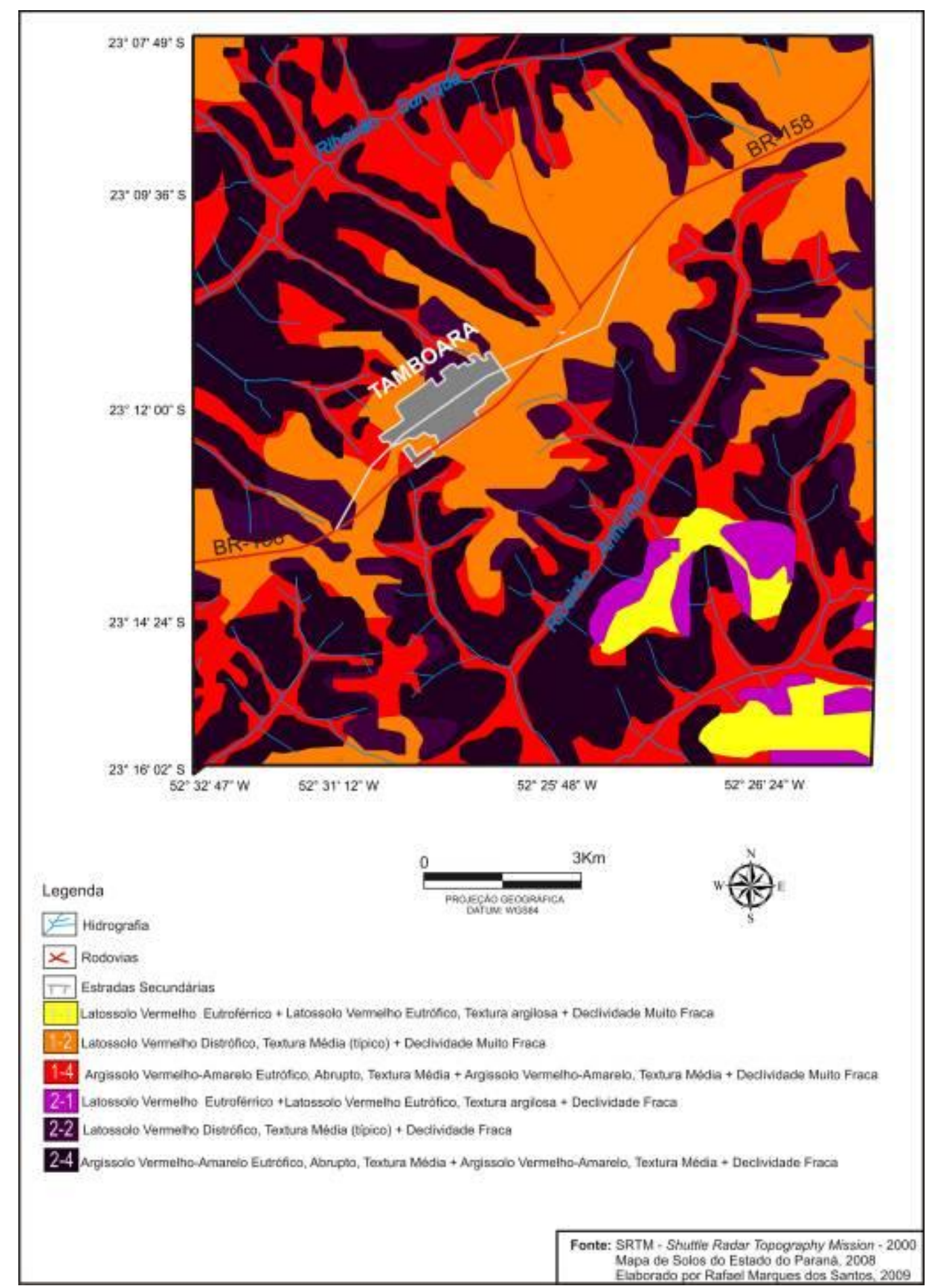

Figura 5. Fragilidade Potencial do município de Tamboara - Paraná. 


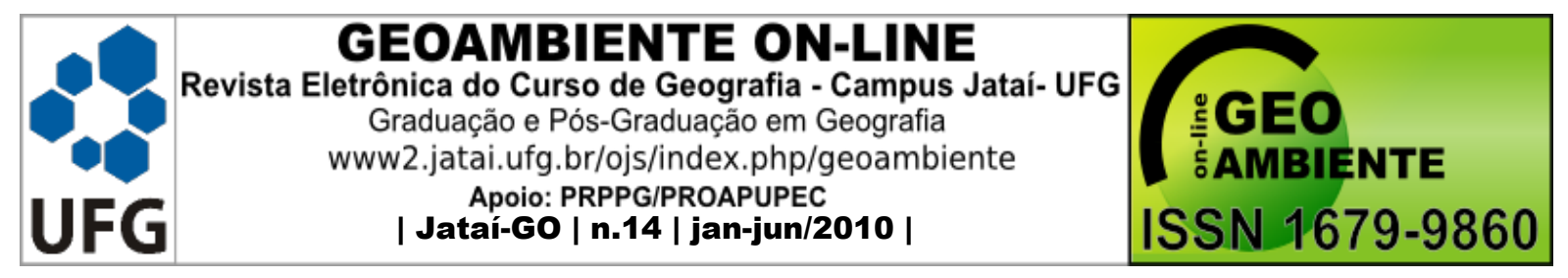

Declividades entre $12 \%$ e $20 \%$ só foram observadas em pequenas áreas, isoladas, localizadas principalmente na baixa vertente. Os segmentos mais extensos ocorrem ao longo das vertentes do ribeirão Suruquá e dos seus tributários. As vertentes da margem direita do ribeirão Anhumai, também exibem segmentos de maior declividade, só que menos contínuos, ora na média, ora na baixa vertente. São setores que apresentam fragilidade média e também estão recobertos pelos Argissolos. Como na situação anterior, esses solos acentuam a fragilidade, conferindo grau forte quando se trata de Argissolos de textura média e moderado para os de textura mais argilosa.

A maior parte do município de Tamboara está ocupada por pastagens e culturas temporárias, representadas pela cana-de-açúcar e mandioca, principalmente. A cana-de-açúcar ocupa de forma mais contínua e se constitui em atividade predominante na porção SE do município, no compartimento Vale do Anhumaí, enquanto que a pastagem com as culturas temporárias entremeadas ocorre no restante da área. Para a fragilidade emergente (Figuras 6 e 7), as culturas temporárias conferem um grau de proteção baixo a muito baixo, dependendo se na área ocorre praticas de atividades conservacionistas, enquanto que as pastagens conferem um grau de proteção médio a alto, dependendo da intensidade do pastoreio.

Deste modo, observa-se que apesar da fragilidade potencial muito fraca a fraca que ocorre no Vale do Anhumai, em virtude da textura mais argilosa dos seus solos, a atividade agrícola constituída predominantemente por cultivos temporários atribui a esse meio uma fragilidade ambiental emergente mais elevada do que para as áreas recobertas por pastagem.

No restante da área do município, a fragilidade potencial é mais elevada em decorrência dos solos de textura média. Quando essas áreas estão ocupadas por pastagem com baixo pisoteio a fragilidade emergente é amenizada pelo grau de proteção alto a médio conferido por esse uso. Entretanto, quando são submetidas a cultivos temporários, aumenta a sua vulnerabilidade.

A maior parte da área do município possui solos de textura arenosa em decorrência da sua litologia, sendo ela o arenito Caiuá. Por este motivo poderíamos considerar esta área proveniente de solos mais arenosos como mais susceptíveis a ocorrência de processos erosivos, na fragilidade emergente esta porção encontra-se mais estável do que a proveniente de solos mais argilosos, em decorrência do uso do solo, em sua grande maioria ocupada por pastagens de baixo pisoteio, principalmente no platô elevado de Tamboara, dando assim um 


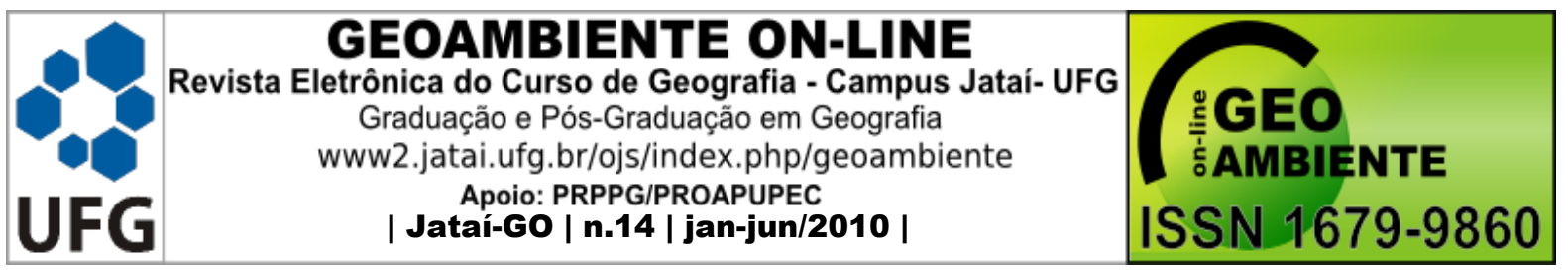

grau maior de proteção a esta área, associado também a baixa declividade de 0 a $6 \%$, sendo classificada segundo a metodologia adotada como de grau muito fraco.

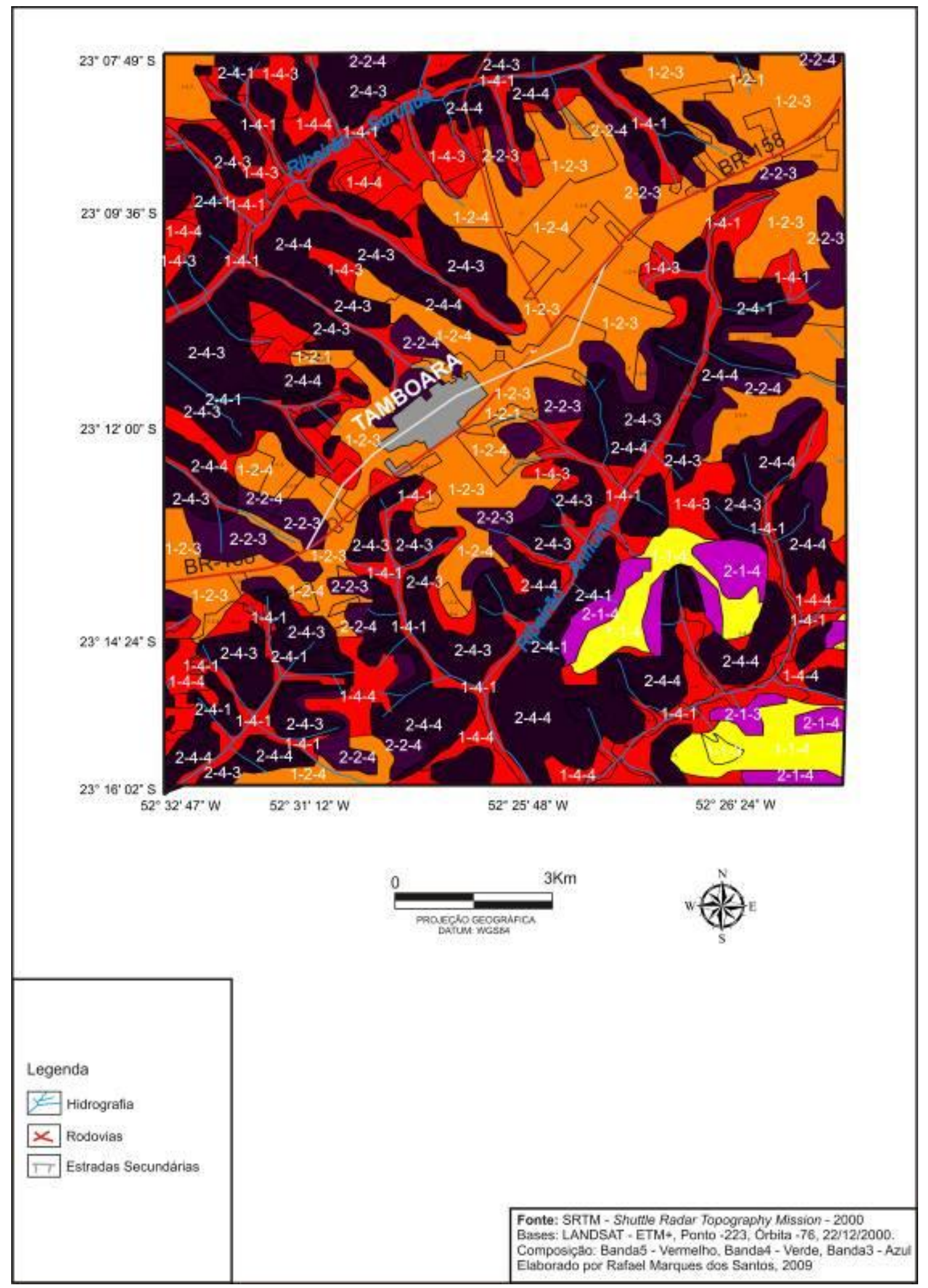

Figuras 6: Mapa de Fragilidade emergente do município de Tamboara - Paraná. 


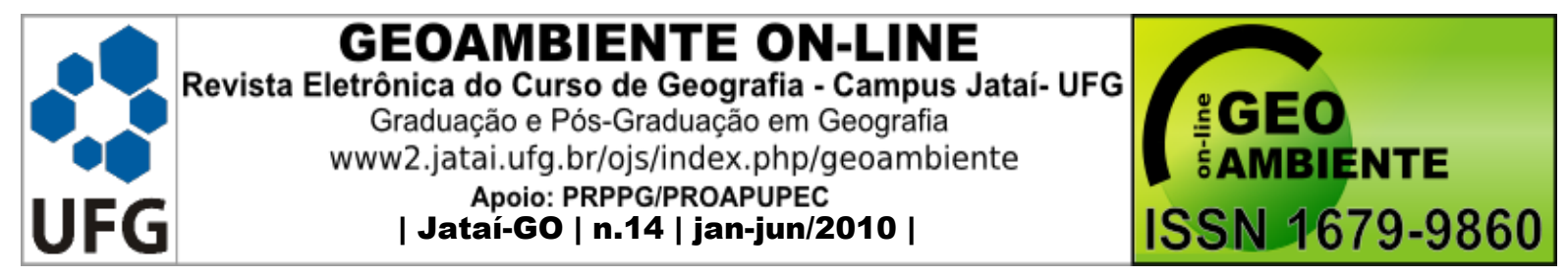

\begin{tabular}{|c|c|c|c|}
\hline & Fragilidade Potencial & & Fragilidade Emergente \\
\hline Cor & Caracteristicas & & Caracteristicas \\
\hline & \multirow{2}{*}{$\begin{array}{l}\text { Declividade Muito Fraca, com presença do Latossolo } \\
\text { Vermelho Eutroférrico e Latossolo Vermelho Eutrófico }\end{array}$} & $1-1-3$ & Fragilidade Potencial mais o Uso do Solo com Pastagens \\
\hline & & $1-1-4$ & $\begin{array}{l}\text { Fragilidade Potencial mais o Uso do Solo com culturas de } \\
\text { ciclo curto (milho, soja, algodăo, mandioca, cana de açúcar) }\end{array}$ \\
\hline \multirow{4}{*}{-} & \multirow{4}{*}{$\begin{array}{l}\text { Declividade Muito Fraca, com presença do Latossolo } \\
\text { Vermelho Distrófico, Textura Média (típico) }\end{array}$} & $1-2-1$ & Fragilidade Potencial mais o Uso do Solo com Mata \\
\hline & & $1-2-3$ & Fragilidade Potencial mais o Uso do Solo com Pastagens \\
\hline & & $1-2-4$ & $\begin{array}{l}\text { Fragilidade Potencial mais o Uso do Solo com culturas de } \\
\text { ciclo curto (milho, soja, algodăo, mandioca, cana de açúcar) }\end{array}$ \\
\hline & & $1-2-5$ & $\begin{array}{c}\text { Fragilidade Potencial mais o Uso do Solo com solo esposto } \\
\text { ao longo de caminhos e estradas, terraplanagens }\end{array}$ \\
\hline \multirow{3}{*}{14} & \multirow{3}{*}{$\begin{array}{l}\text { Declividade Muito fraca, com presença do } \\
\text { Argissolo Vermelho-Amarelo Eutrófico, Abrupto, } \\
\text { Textura Média e Argissolo Vermelho-Amarelo, } \\
\text { Textura Média }\end{array}$} & $1-4-1$ & Fragilidade Potencial mais o Uso do Solo com Mata \\
\hline & & $1-4-3$ & Fragilidade Potencial mais o Uso do Solo com Pastagens \\
\hline & & $1-4-4$ & $\begin{array}{l}\text { Fragilidade Potencial mais o Uso do Solo com culturas de } \\
\text { ciclo curto (milho, soja, algodăo, mandioca, cana de açuccar) }\end{array}$ \\
\hline \multirow{2}{*}{$2-1$} & \multirow{2}{*}{$\begin{array}{l}\text { Declividade Fraca, com presença do Latossolo } \\
\text { Vermelho Eutroférrico e Latossolo Vermelho Eutrófico }\end{array}$} & $2-1-3$ & Fragilidade Potencial mais o Uso do Solo com Pastagens \\
\hline & & $2-1-4$ & $\begin{array}{l}\text { Fragilidade Potencial mais o Uso do Solo com culturas de } \\
\text { ciclo curto (milho, soja, algodão, mandioca, cana de açucar) }\end{array}$ \\
\hline \multirow{3}{*}{$2-2$} & \multirow{3}{*}{$\begin{array}{l}\text { Declividade Fraca, com presença do Latossolo } \\
\text { Vermelho Distrófico, Textura Média (tipico) }\end{array}$} & $2-2-1$ & Fragulidade Potencial mais o Uso do Solo com Mata \\
\hline & & $2-2-3$ & Fragilidade Potencial mais o Uso do Solo com Pastagens \\
\hline & & $2-2-4$ & $\begin{array}{l}\text { Fragilidade Potencial mais o Uso do Solo com culturas de } \\
\text { ciclo curto (milho, soja, algodăo, mandioca, cana de açúcar) }\end{array}$ \\
\hline \multirow{3}{*}{$2-4$} & \multirow{3}{*}{$\begin{array}{l}\text { Declividade fraca, com presença do } \\
\text { Argissolo Vermelho-Amarelo Eutrófico, Abrupto, } \\
\text { Textura Média e Argissolo Vermelho-Amarelo, } \\
\text { Textura Média }\end{array}$} & $2-4-1$ & Fragilidade Potencial mais o Uso do Solo com Mata \\
\hline & & $2-4-3$ & Fragilidade Potencial mais o Uso do Solo com Pastagens \\
\hline & & $2-4-4$ & $\begin{array}{l}\text { Fragilidade Potencial mais o Uso do Solo com culturas de } \\
\text { ciclo curto (milho, soja, algodáo, mandioca, cana de açúcar) }\end{array}$ \\
\hline
\end{tabular}

Figura 7: Legenda Integrada do Mapa de Fragilidade Emergente

\subsection{Metodologia 2 - Mapas de Fragilidade Potencial e Emergente com apoio no mapa grau de dissecação do relevo}

A carta de padrão de formas de relevo ou carta de dissecação do relevo (Figura 08), utilizando-se a matriz dos índices de dissecação do relevo (Tabela 1), apresentada por Ross (1992), se fundamenta na relação da densidade de drenagem/distância interfluvial média, definindo assim diferentes intensidades dos patrões de dissecação do relevo. Utilizando o programa de geoprocessamento Global Mapper como ferramenta de análise, mensurou-se a 


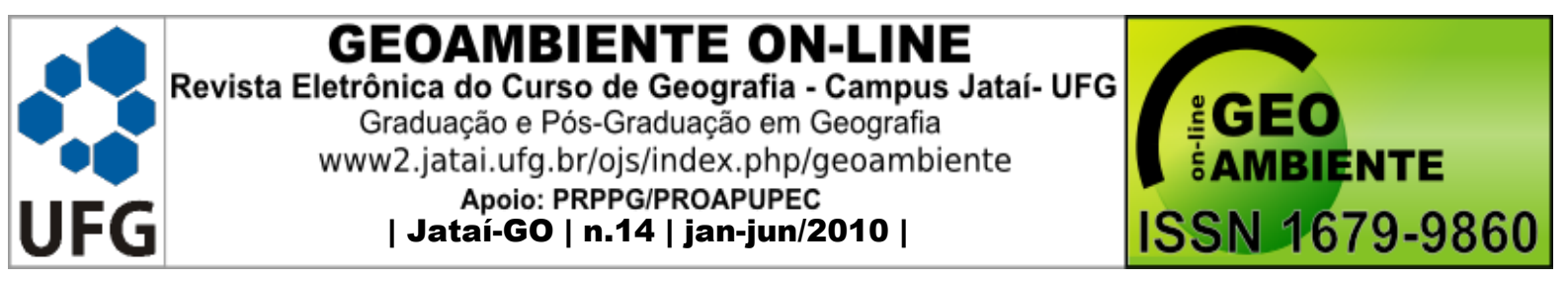

medida entre um canal e outro. Para a determinação da distância interfluvial foram realizadas medidas sempre entre os cursos de segunda ordem e nos seus setores médios. Nos mesmos segmentos foram medidos, também, os entalhes.

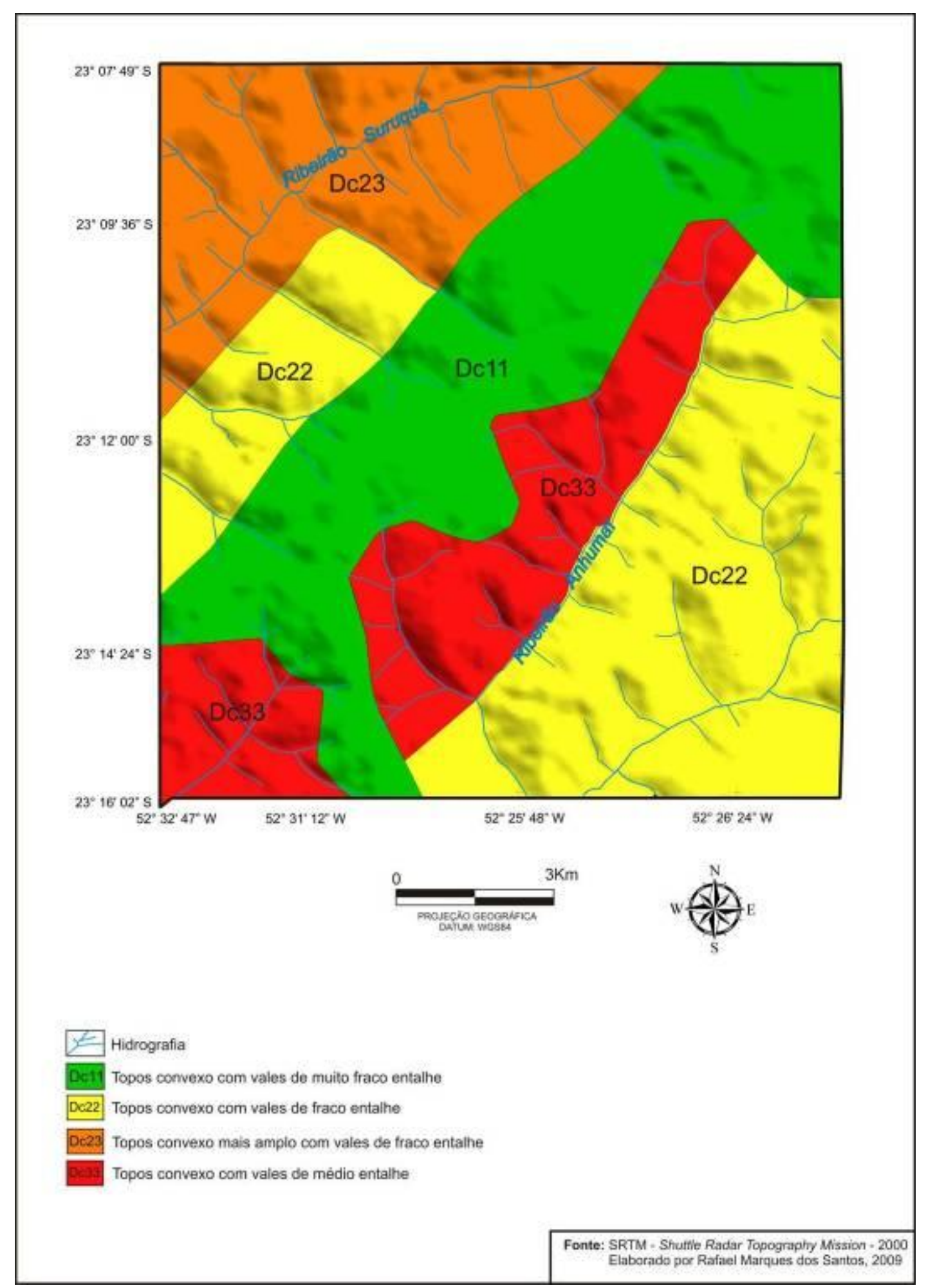

Figura 08. Dissecação do município de Tamboara - Paraná. 


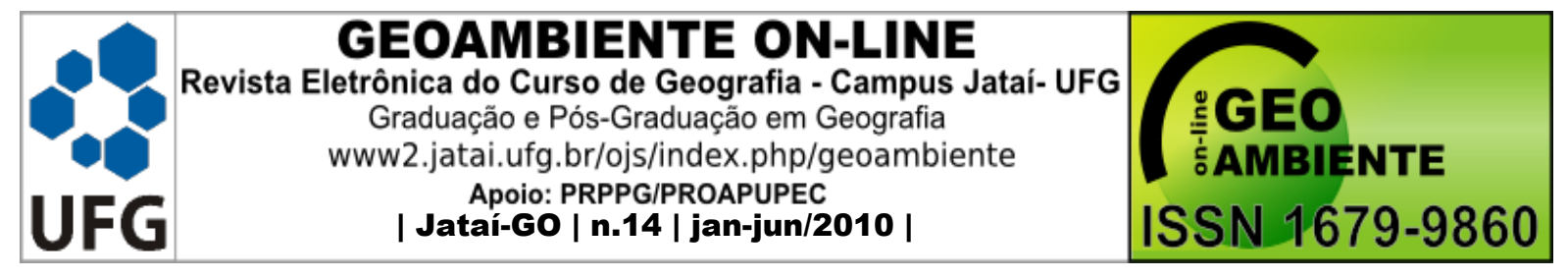

No caso dos entalhes foi necessário a geração de curvas de níveis, registrando-se a diferença altimétrica entre o ponto mais alto e mais baixo entre os canais da rede de drenagem. Com estas medidas foi possível aplicar a matriz dos índices de dissecação do relevo, aplicável para escalas médias, apresentada e adaptada por Ross (1992), a partir daquela empregada pelo Projeto RADAM Brasil.

Concomitantemente à determinação do grau de dissecação procedeu-se à identificação dos padrões de formas, como propostos na Tabela 05, apresentada por Ross (1996).

Tabela 05. Padrões de Formas de Relevo

\begin{tabular}{|l|l|}
\hline FORMAS DE DENUDAÇÃO & FORMAS DE ACUMULAÇÃO \\
\hline D - Denudação (erosão) & A - Acumulação (deposição) \\
Da - Formas com topos aguçados & Apf - Formas de planície fluvial \\
Dc - Formas com topos convexos & Apm - Formas de planície marinhas \\
Dt - Formas com topos tabulares & Apl - Formas de planície lacustre \\
Dp - Formas de superfície planas & Api - Formas de planície interdidal (mangue) \\
De - Formas de escarpas & Ad - Formas de campos de dunas \\
Dv - formas de vertentes & Atf - Formas de terraços fluviais \\
& Atm - Formas de terraços marinhos \\
\hline
\end{tabular}

Como pode ser observado na carta de dissecação elaborada verifica-se que os graus de entalhamento variaram de muito fraco a médio, enquanto que a dimensão interfluvial média variou de muito grande a média. Com relação aos padrões de formas de relevo encontra-se em toda área formas de denudacionais (erosão) de topos convexos (Dc). Cerca de $57 \mathrm{~km}^{2}$ da área apresentou índice de 11, localizado na parte central do município denominada de platô elevado de Tamboara, onde esta instalada a área urbana da cidade, representando assim uma área de topo plano com baixa densidade de drenagem e com grau de entalhamento muito fraco, sendo que o primeiro numero da matriz representa o entalhamento médio dos vales e o segundo numero representa a dimensão interfluvial médio entre os canais.

No vale do ribeirão Anhumaí, no setor sudeste do município, cerca de $51,5 \mathrm{~km}^{2}$ apresentou o índice 22, indicando grau de entalhamento baixo e dimensão interfluvial grande. O entalhamento varia de 40 a $80 \mathrm{~m}$, correspondendo em termos gerais a um compartimento rebaixado, constituído por colinas médias, com topos arredondados e vertentes longas 


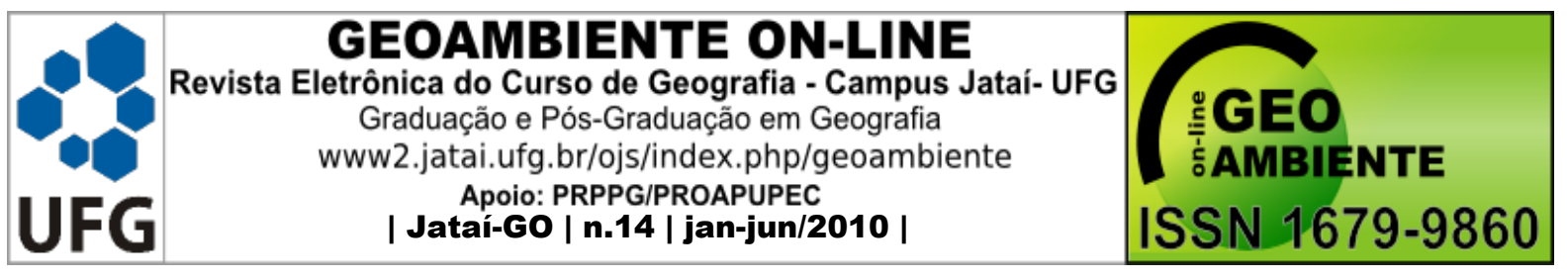

convexo-retilíneas. Entretanto, nas vertentes da margem esquerda do ribeirão Anhumaí, ocorre uma área com cerca de $30 \mathrm{~km}^{2}$ de área onde o índice de dissecação é 33 - grau de entalhamento médio, variando de 80 a 160m, e dimensão interfluvial média. Está área é a que apresenta o grau de entalhamento mais alto de todo o município. No setor Noroeste, onde se encontra o ribeirão Suruquá, o índice aparece como 23, correspondendo a um grau de entalhamento fraco, mas com dimensão interfluvial média. Nessa área ocorre um padrão de drenagem paralela com distancias mais curtas entre os canais.

A carta de Fragilidade Potencial (Carta de dissecação X Solos - Figura 9), do município de Tamboara, evidenciou na área central do município, compartimento denominado de Platô Elevado de Tamboara, muito baixo grau de fragilidade, com vales de entalhe muito fraco, associados predominantemente à presença do Latossolo Vermelho distrófico, textura média (típico), derivados do arenito Caiuá. Este setor, mesmo tendo solos arenosos, é considerado, em função do seu grau de dissecação, o de mais baixa fragilidade, ou seja, o setor mais estável. É aqui que está instalada a área urbana do município de Tamboara.

No setor sudeste de Tamboara, no vale do ribeirão Anhumaí, na margem direita, identifica-se grau de fragilidade baixo. Os vales apresentam fraco entalhe e estão associados preferencialmente a solos de textura argilosa e, secundariamente, textura média, o que gera uma variação no grau de fragilidade. Os solos arenosos como foi evidenciado a presença do Argissolo Vermelho-Amarelo, textura média e do Latossolo Vermelho distrófico, textura média (típico) são mais susceptíveis a processos de erosão por isso o seu grau de fragilidade é maior em relação àqueles de textura argilosa, como Latossolo Vermelho eutrófico, textura argilosa, sendo estes mais estáveis e, portanto, menos susceptíveis a processos erosivos.

Por se tratar de uma área de contato arenito/basalto, as variações texturais dos solos se mostraram muito importantes na definição do grau de fragilidade, já que a área é relativamente homogênea, tendo pouca variação na dissecação do relevo.

A área que abrange o vale do ribeirão Suruquá, é a que apresenta o maior grau de fragilidade no município. Apresenta entalhe fraco a médio, com distâncias interfluviais predominantemente médias. Este setor é considerado instável na fragilidade potencial, por estar associado aos maiores graus de dissecação e solos de textura arenosa, sendo, portanto, mais susceptível a processos erosivos. 


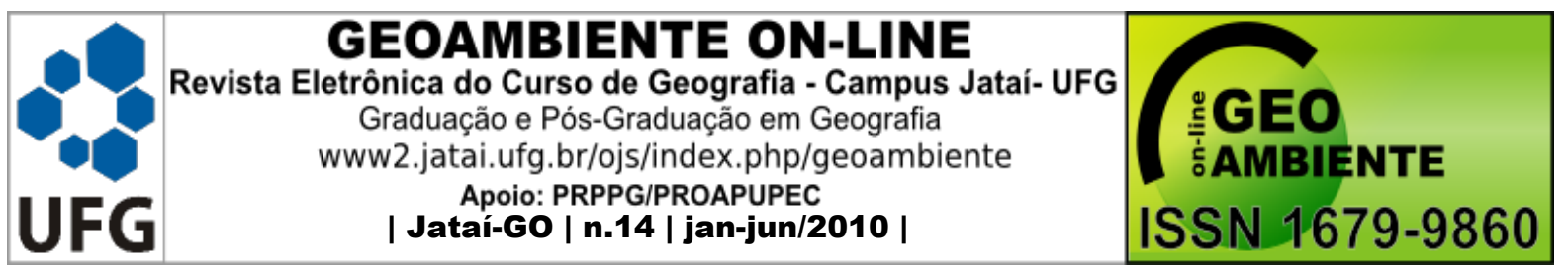

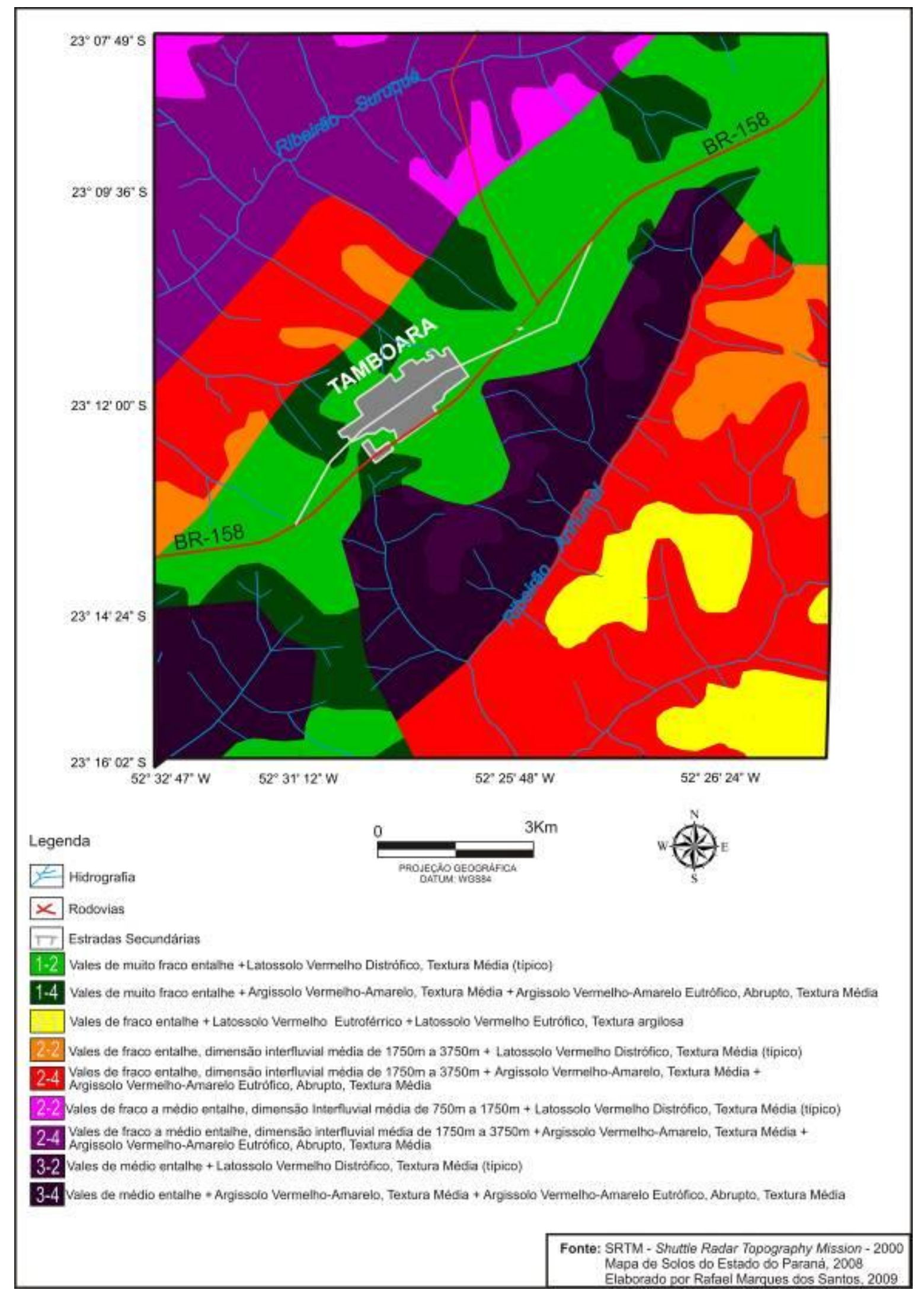

Figura 09. Fragilidade Potencial (Dissecação x Solos) do município de Tamboara - Paraná. 


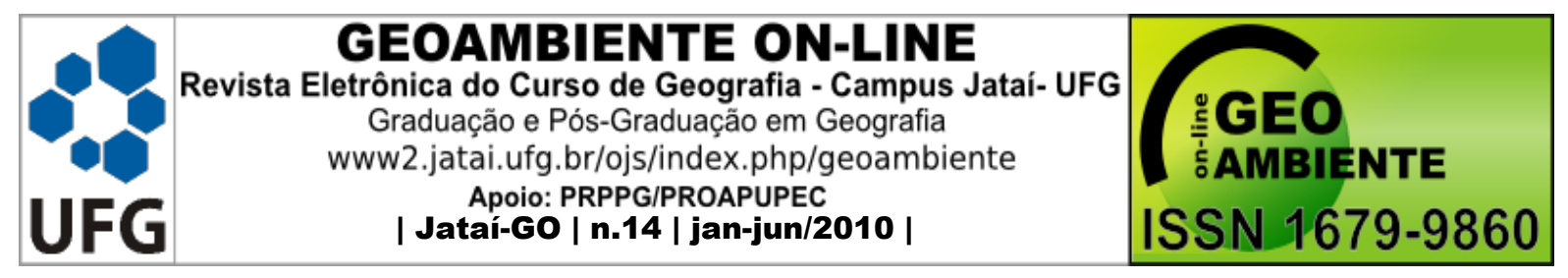

A Fragilidade Emergente (Fragilidade Potencial x Uso do Solo - Figuras 10 e 11) constatou - se que no vale do ribeirão Suruquá, onde registra-se a fragilidade potencial mais alta no município, ocorre na maior parte da área o uso do solo com pastagens, o que ameniza, de um certo modo, o seu grau de fragilidade, pois as pastagens sem muito pisoteio do gado, correspondem a um grau médio de fragilidade, dando assim mais estabilidade a este setor.

No vale do ribeirão Anhumaí, que apresenta baixo grau de dissecação e de fragilidade potencial, onde ocorre principalmente a presença de solos argilosos, na fragilidade emergente o grau de fragilidade é maior por conta do seu uso do solo que de forma homogênea e por influência da proximidade com a Usina de beneficiamento de cana de açúcar COOPCANA, neste setor domina a cultura temporária. A principal cultura temporária no local é a cana de açúcar, acrescendo assim um maior grau de fragilidade.

Já a parte central do município é a área mais estável por conta de apresentar entalhe muito baixo nos vales, grau de fragilidade muito baixa, apresentando como principal forma de uso do solo, a pastagem, considerada de médio grau de fragilidade. 


\begin{tabular}{|c|c|c|}
\hline & $\begin{array}{l}\text { GEOAMBIENTE ON-L } \\
\text { Revista Eletrônica do Curso de Geografia - Car } \\
\text { Graduacăo e Pós-Graduacăo em Geo } \\
\text { www2.jatai.ufg.br/ojs/index.php/geo } \\
\text { Apoio: PRPPG/PROAPUPEC } \\
\text { | Jatai-Go | n.14 | jan-jun/201 }\end{array}$ & ISSN \\
\hline
\end{tabular}

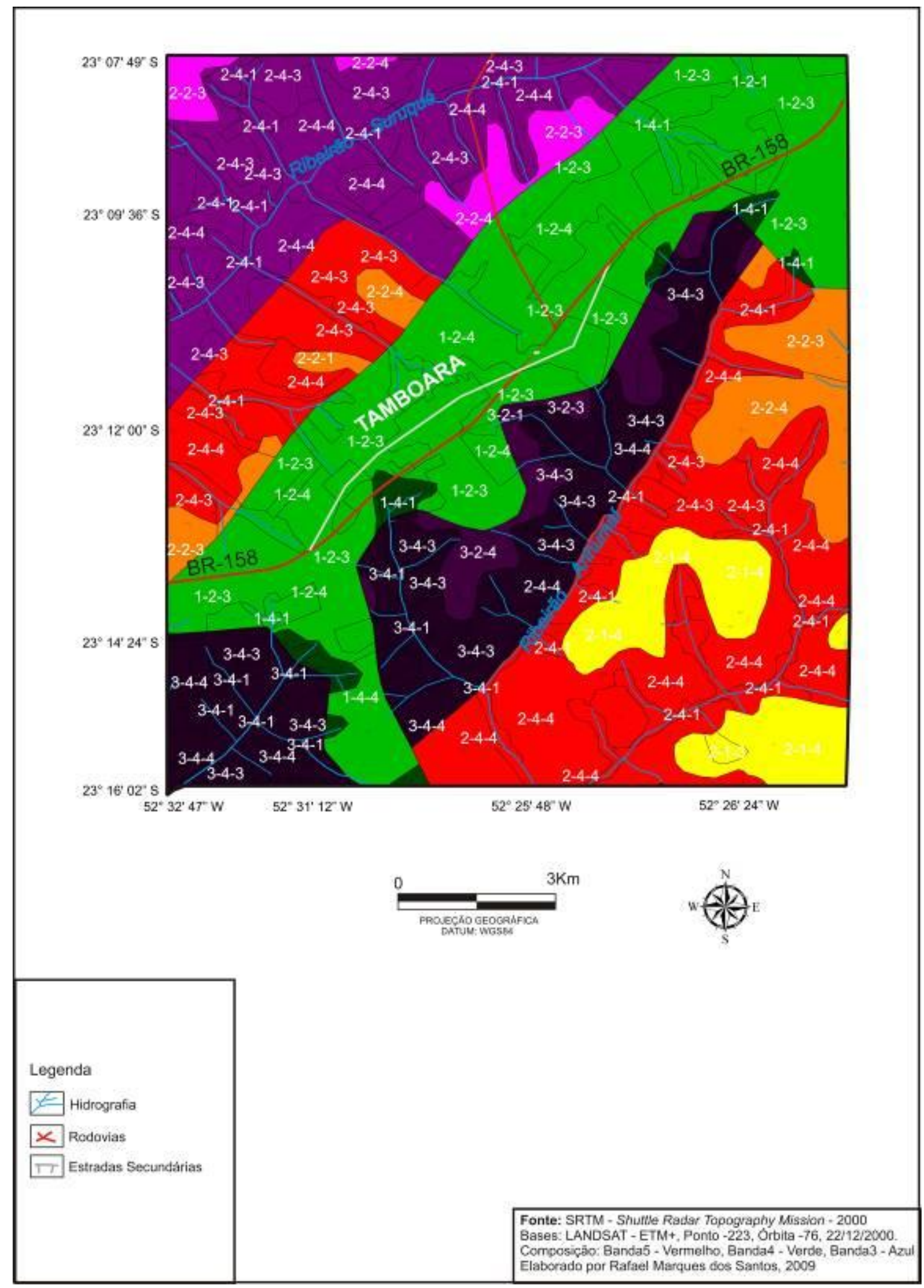

Figura 10: Fragilidade Emergente (Dissecação x Solos) do município de Tamboara - Paraná. 


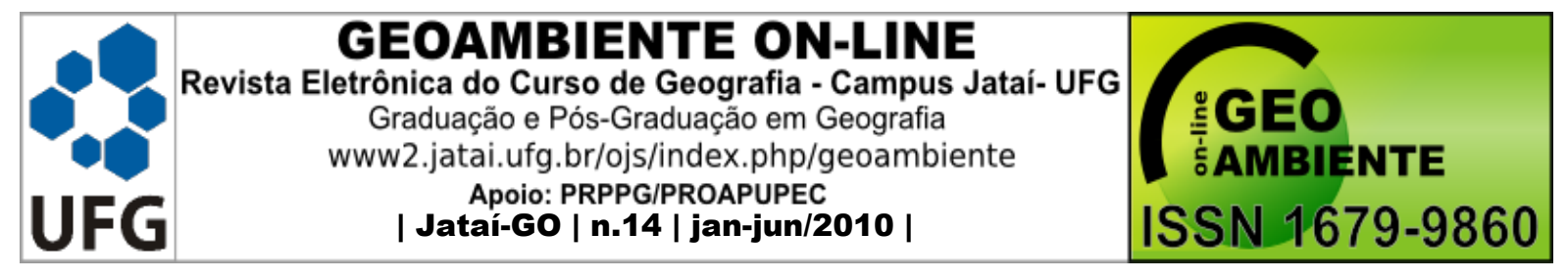

\begin{tabular}{|c|c|c|c|}
\hline & Fragilidade Potencial & & Fragilidade Emergente \\
\hline Cor & Caracteristicas & & Caracteristicas \\
\hline \multirow{3}{*}{$1-2$} & \multirow{3}{*}{$\begin{array}{l}\text { Vales de muito fraco entalhe, com a presença do } \\
\text { Latossolo Vermelho Distrófico, Textura Média (tipico) }\end{array}$} & $1-2-1$ & Fragilidade Potenclal mais o Uso do Solo com Mata \\
\hline & & $1-2-3$ & Fragilidade Potenciai mais o Uso do Solo com Pastagens \\
\hline & & $1-2-4$ & $\begin{array}{l}\text { Fragilidade Potencial mais o Uso do Solo com culturas de } \\
\text { ciclo curto (milho, soja, algodäo, mandioca, cana de açücar) }\end{array}$ \\
\hline & \multirow{3}{*}{$\begin{array}{l}\text { Vales de muito fraco entalhe, com a presença do } \\
\text { Argissolo Vermelho-Amarelo Eutrófico, Abrupto. } \\
\text { Textura Média e Argissolo Vermelho - Amarelo, textura } \\
\text { média }\end{array}$} & $1-4-1$ & Fraglilidade Potencial mais o Uso do Solo com Mata \\
\hline & & $1-4-3$ & Fragilidade Potencial mais o Uso do Solo com Pastagens \\
\hline & & $1-4-4$ & $\begin{array}{l}\text { Fragilidade Potencial mais o Uso do Solo com culturas de } \\
\text { ciclo curto (milho, soja, algodáo, mandioca, cana de açucar) }\end{array}$ \\
\hline & \multirow{2}{*}{$\begin{array}{l}\text { Vales de fraco entalhe, com a presença do Latossolo } \\
\text { Vermelho Eutroférrico e Latossolo Vermelho } \\
\text { Eutrófico, textura argilosa }\end{array}$} & $2-1-3$ & Fragilidade Potencial mais o Uso do Solo com Mata \\
\hline & & $2-1-4$ & Fragilidade Potencial mais o Uso do Solo com Pastagens \\
\hline \multirow{3}{*}{$2-2$} & \multirow{3}{*}{$\begin{array}{l}\text { Vales de fraco entalhe, Dimensāo interfluvial } \\
\text { de } 1750 \text { a } 3750 \text {, com a presença, do } \\
\text { Latossolo Vermelho Distrófico, Textura Média (tipico) }\end{array}$} & $2-2-1$ & Fragilidade Potencial mais o Uso do Solo com Mata \\
\hline & & $2-2-3$ & Fragilidade Potencial mais o Uso do Solo com Pastagens \\
\hline & & $2-2-4$ & $\begin{array}{l}\text { Fragilildade Potencial mais o Uso do Solo com culturas de } \\
\text { ciclo curto (milho, soja, algodło, mandioca, cana de açucar }\end{array}$ \\
\hline \multirow{3}{*}{$2-4$} & \multirow{3}{*}{$\begin{array}{l}\text { Vales de fraco entalhe, Dimensăo interfluvial } \\
\text { de } 1750 \text { a } 3750 \text {, com presença do } \\
\text { Argissolo Vermelho-Amarelo Eutrófico, Abrupto, } \\
\text { Textura Média e Argissolo Vermeiho-Amarelo, } \\
\text { Textura Mèdia }\end{array}$} & 2-4-1 & Fragilidade Potencial mais o Uso do Solo com Mata \\
\hline & & $2-4-3$ & Fragilidade Potencial mais o Uso do Solo com Pastagens \\
\hline & & $2-4-4$ & $\begin{array}{l}\text { Fragilidade Potencial mais o Uso do Solo com culturas de } \\
\text { ciclo curto (milho, soja, algodăo, mandioca, cana de açúcar) }\end{array}$ \\
\hline \multirow{3}{*}{$2 \cdot 2$} & \multirow{3}{*}{$\begin{array}{l}\text { Vales de fraco a médio entalhe. Dimensão interfluvial } \\
\text { de } 750 \text { a } 1750 \text {. com a presença do e } \\
\text { Latossolo Vermelho Distrófico, Textura Mèdia (típico) }\end{array}$} & $2-3-1$ & Fragilidade Potencial mais o Uso do Solo com Mata \\
\hline & & 2-3-3 & Fragilidade Potencial mais o Uso do Solo com Pastagens \\
\hline & & $2-3-4$ & $\begin{array}{l}\text { Fragilidade Potencial mais o Uso do Solo com culturas de } \\
\text { ciclo curto (milho, soja, algodio, mandioca, cana de açucar) }\end{array}$ \\
\hline \multirow{3}{*}{$2-4$} & \multirow{3}{*}{$\begin{array}{l}\text { Vales de fraco a médio entalhe, Dimensăo interfluvial } \\
750 \mathrm{~m} \text { a } 1750 \mathrm{~m}, \mathrm{com} \text { presenç̧a do } \\
\text { Argissolo Vermelho-Amarelo Eutrófico, Abrupto; } \\
\text { Textura Média e Argissolo Vermelho-Amarelo, } \\
\text { Textura Média, } \\
\end{array}$} & 2-4-1 & Fragilidade Potencial mais o Uso do Solo com Mata \\
\hline & & $2-4-3$ & Fragilidade Potencial mais o Uso do Solo com Pastagens \\
\hline & & $2-4-4$ & $\begin{array}{l}\text { Fragilidade Potencial mais o Uso do Solo com culturas de } \\
\text { ticlo curto (milho, soja, algodão, mandioca, cana de açucar) }\end{array}$ \\
\hline \multirow{3}{*}{$3-2$} & \multirow{3}{*}{$\begin{array}{l}\text { Vales de médio entalhe, com presença do } \\
\text { Latossolo Vermelho Distrófico, Textura Média (tipico) }\end{array}$} & $3-2-1$ & Fragilidade Potencial mais o Uso do Solo com Mata \\
\hline & & 3-2-3 & Fragilidade Potencial mais o Uso do Solo com Pastagens \\
\hline & & $3-2-4$ & $\begin{array}{l}\text { Fragilidade Potencial mais o Uso do Solo com culturas de } \\
\text { ciclo curto (milho, soja, algodăo, mandioca, cana de açucar) }\end{array}$ \\
\hline \multirow{3}{*}{$3-4$} & \multirow{3}{*}{$\begin{array}{l}\text { Vales de médio entalhe, com presença do } \\
\text { Argissolo Vermelho-Amarelo Eutrófico, Abrupto, } \\
\text { Textura Média e Argissolo Vermelho-Amarelo, } \\
\text { Textura Média }\end{array}$} & $3-4-1$ & Fragilidade Potencial mais o Uso do Solo com Mata \\
\hline & & $3-4-3$ & Fragilidade Potencial mais o Uso do Solo com Pastagens \\
\hline & & $3-4-4$ & $\begin{array}{l}\text { Fragilidade Potencial mais o Uso do Solo com culturas de } \\
\text { ciclo curto (milho, soja, algodio, mandioca, cana de açucar) }\end{array}$ \\
\hline
\end{tabular}

Figura 11. Legenda Integrada do Mapa de Fragilidade Emergente 


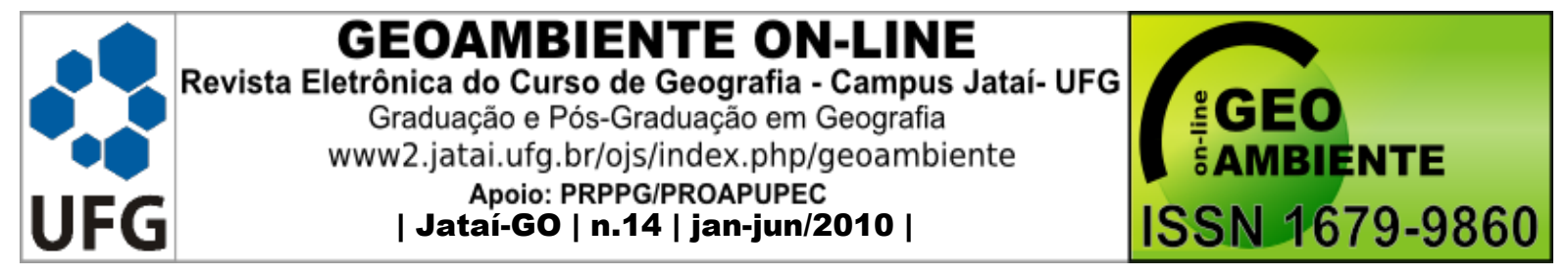

\section{4 - Correlação entre as duas metodologias apresentadas por Ross (1994)}

Com relação aos dois procedimentos técnico-operacionais propostos por ROSS (1994), a única diversificação com relação as variáveis é a derivação entre a aplicação dos índices de dissecação do relevo e as classes de declividade. As outras variáveis, solos, uso do solo e clima são aplicadas igualmente para estes dois procedimentos medotológicos (SPORL, 2001).

As diferenças apresentadas em cada um dos dois modelos resultaram na definição de diferentes graus de fragilidade potencial. Modelo proposto por Ross (1994) utilizando-se os Índices de dissecação do Relevo classificou a área em 3 diferente graus de fragilidade ( Muito Fraca, Fraca e Média), já o outro modelo proposto por Ross (1994) utilizando-se as Classes de declividade, classificou a área em 2 graus de fragilidade Muito Fraca e Fraca.

Já na Fragilidade Emergente seguiu-se o mesmo resultado apresentado na fragilidade potencial, com um diferencial de que a fragilidade emergente baseada nos índices de dissecação do relevo apresentou mais subdivisões de classes, resultando em uma forma de análise mais completa e detalhada.

\section{5 - Considerações Finais}

A carta de fragilidade potencial obtida pelo confronto das classes de declividades com os tipos de solos mostrou diferentes graus de fragilidade potencial ao longo do território municipal, destacando-se o setor Sudeste (sobre basalto) que apresenta fragilidade muito baixa a baixa nos topos e moderada ao longo das vertentes. Entretanto, na fragilidade emergente demonstra que com o uso com culturas temporárias eleva a sua vulnerabilidade. No restante da área (sobre o arenito) a fragilidade potencial muito fraca a fraca, resultante das características da declividade, é elevada pela textura mais arenosa dos seus solos, passando à média nos topos e a forte nas vertentes. O uso com pastagem possibilita um grau médio a alto de cobertura, enquanto que as culturas temporárias, contribuem para a exacerbação da vulnerabilidade natural nessas áreas apresentados na fragilidade emergente.

Neste trabalho constatou que a metodologia que se apóia no grau de dissecação do relevo se mostrou a mais eficaz, pois relacionando com a dinâmica encontrada em campo conseguiu concretizar as áreas de fragilidade do município.

O principal problema observado está relacionado à atribuição de "pesos" às variáveis. Estes pesos devem indicar a contribuição relativa de cada uma das variáveis (relevo, solo, 


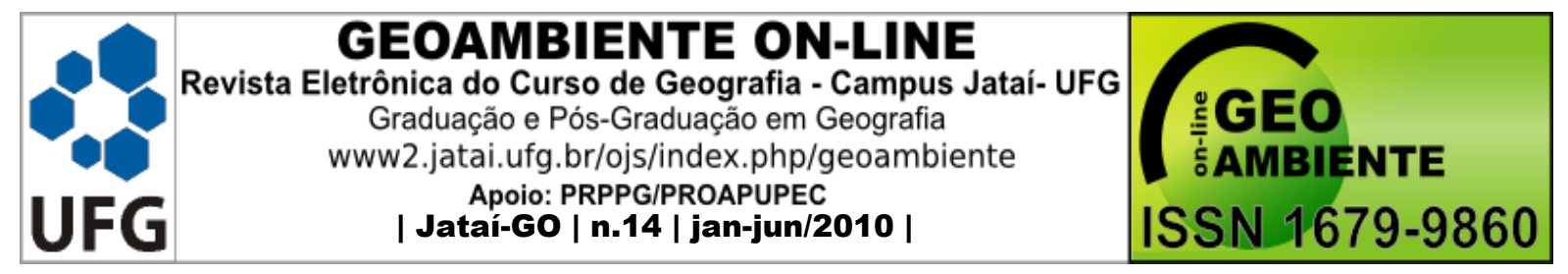

rocha, cobertura vegetal e clima) na determinação do grau de fragilidade de uma área. Entretanto, em uma área de contado litológico e com o relevo homogêneo, os solos são fundamentais para a graduação da fragilidade, por sua diferenciação em solos arenosos mais susceptíveis e argilosos menos susceptíveis. Este fato, dificuldade em atribuir pesos a cada uma destas variáveis, é o que explica as divergências apresentadas entre os modelos de fragilidade ambiental avaliados.

Com a análise comparativa dos modelos procurou -se apontar aspectos positivos e negativos, contribuindo para o aprimoramento dos mesmos e para o desenvolvimento de outros modelos de análise da fragilidade ambiental para cada tipo de área abordada, pois estes modelos representam um importante instrumento para tomada de decisões necessárias ao processo de gestão Territorial e gestão ambiental.

\section{6 - Referências}

CARNASCIALI, C. H. Conseqüências sociais das transformações tecnológicas na agricultura do Paraná IN: MARTINE, G. \& GARCIA, R. C. Os impactos sociais da modernização agrícola. São Paulo: Caetés, 1987.

CREPANI, E.; MEDEIROS, J.S.; AZEVEDO, L.G.; DUARTE, V.; HERNANDEZ, P.; FLORENZANO, T. Curso de Sensoriamento Remoto Aplicado ao Zoneamento EcológicoEconômico. INPE. São José dos Campos, São Paulo, 1996.

FRAISOLI, C. Valorização do espaço e fragilidade ambiental: o caso da construção do meio ambiente urbano da bacia do córrego Santo Antônio, Mogi Mirim. (Dissertação de Mestrado) - Universidade Estadual de Campinas, Instituto de Geociências, Campinas, SP, 2005.

GUERRA, A. J. T. e CUNHA, S. B. Geomorfologia: uma atualização de bases e conceitos.

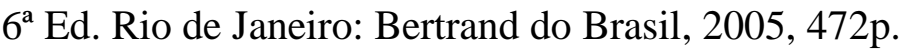

KAWAKUBO, F.S.; MORATO, R.G.; CAMPOS, K.C.; LUCHIARI, AL; ROSS, J.L.S. Caracterização empírica da fragilidade ambiental utilizando geoprocessamento. In: XII Simpósio Brasileiro de Sensoriamento Remoto, Goiânia ... Anais, INPE, pp. 2203-2210, 2005 .

NAKASHIMA, M. Análise dos Processos Erosivos e da Fragilidade Ambiental na bacia do Keller-PR. Tese de Doutorado, FFLCH, USP, São Paulo, 1999

ROSS, J. L. S. Geomorfologia: ambiente e planejamento. São Paulo, Contexto, 1990. 


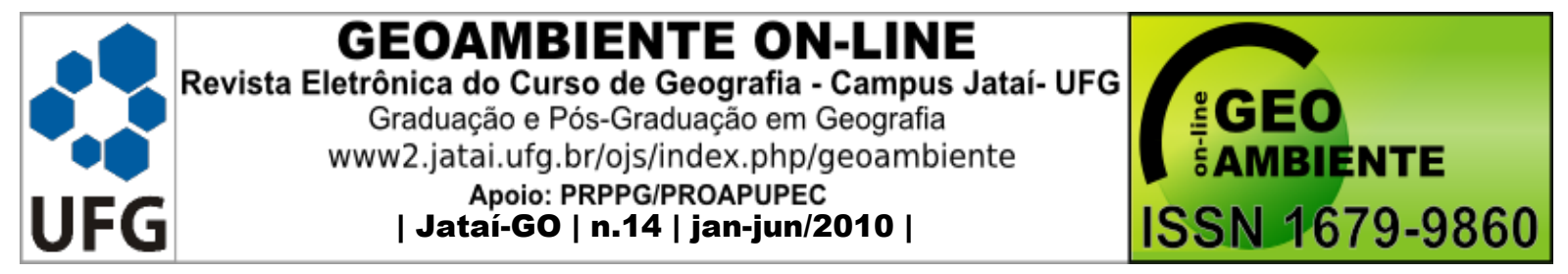

ROSS, J. L. S. O registro cartográfico dos fatos geomórficos e a questão da taxonomia do relevo. São Paulo, Revista do Depto. Geografia, 6:17-30, 1992

ROSS, J. L. S. Análise da fragilidade dos ambientes naturais e antropizados. São Paulo, Revista do Departamento de Geografia, 8:63-74, 1994.

ROSS, J. L. S. Geomorfologia aplicada aos IEAs-RIMAs IN: GUERRA, A. J. T. \& CUNHA, S. B. da (Organizadores), Geomorfologia e meio ambiente. - Rio de Janeiro, Bertrand Brasil, 1996. pp. 291-335

SALA, M. G. Indicadores de fragilidade ambiental na bacia do ribeirão Maringá-PR. (Dissertação de Mestrado) - Universidade Estadual de Maringá - Departamento de Geografia, Maringá, 2005.

SERRA, E. Os primeiros processos de ocupação da terra e a organização pioneira do espaço agrário no Paraná. Maringá, Boletim de Geografia, Ano 10, Nº1, 1992.

SPÖRL, C.; ROSS, J. L. S. Análise comparativa da fragilidade ambiental com aplicação de três modelos. São Paulo, Revista Geousp - Espaço e Tempo, Nº15, pp. 39-49, 2004.

SPÖRL, C. Análise da fragilidade ambiental relevo-solo com aplicação de três modelos alternativos nas altas bacias do rio Jaguari-mirim, ribeirão do Quartel e ribeirão da Prata. São Paulo. Dissertação de Mestrado, Depto. Geografia, USP, 2001, 159p.

STOLLE, L. Simulação e espacialização da fragilidade ambiental em relação ás atividades florestais. Curitiba. Dissertação de Mestrado. Depto. Engenharia Florestal, UFPR, 2008, 91p. TRICART, J. Ecodinâmica. Rio de Janeiro, IBGE, Diretoria Técnica, SUPREN, 1977, 91p.

- Para a obtenção de dados sobre a produção agrícola do município foram consultados os Censos Agropecuários do IBGE:

IBGE (Instituto Brasileiro de Geografia e Estatística). Censo Agropecuário 1995-1996. Disponível em: http://www.ibge.gov.br/servidor_arquivos_est/

IBGE (Instituto Brasileiro de Geografia e Estatística) Censo Agropecuário 2006. Disponível em: http://www.ibge.gov.br/servidor_arquivos_est/ 